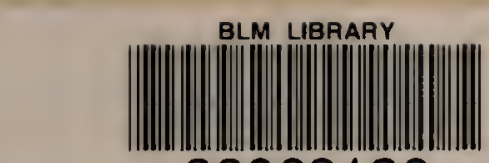

88068126
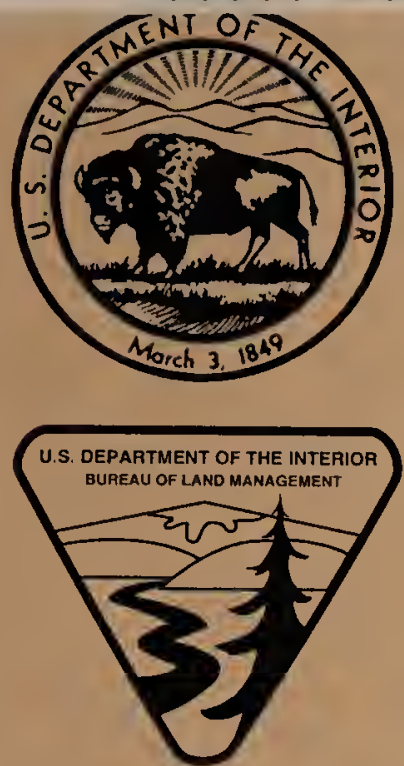

U.S. Department of the Interior Bureau of Land Management

Burns District Office

28910 Hwy 20 West

Hines, Oregon 97738

March 2002

\title{
FY 2002 \\ Planning Update for the Burns District
}

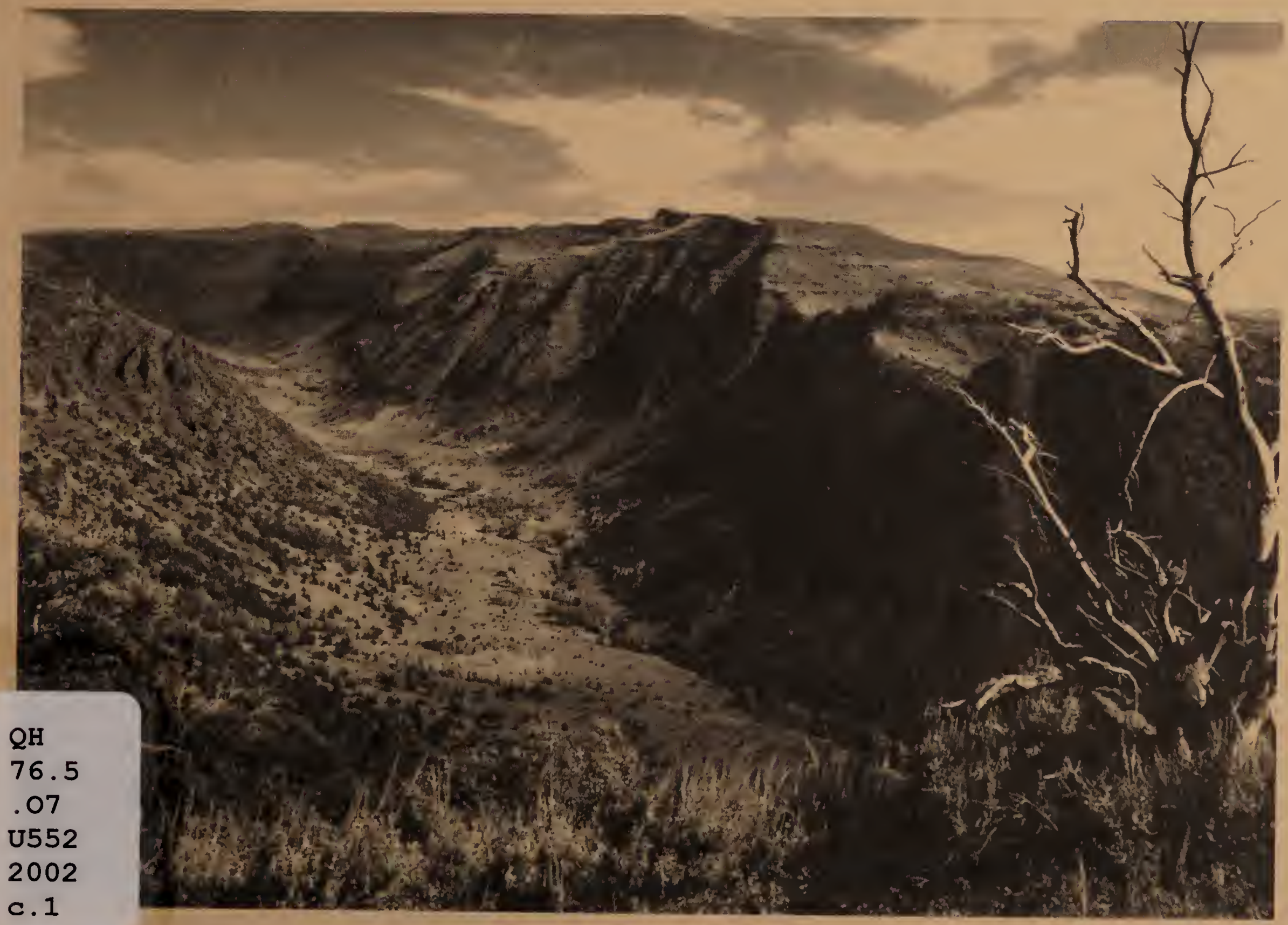


As the Nation's principal conservation agency, the Department of the Interior has responsibility for most of our Nationally-owned public land and natural resources. This includes fostering the wisest uses of our land and water resources, protecting our fish and wildlife, preserving the environmental and cultural values of our National parks and historical places, and providing for the enjoyment of life through outdoor recreation. The Department assesses our energy and mineral resources and works to assure that their development is in the best interest of all our people. The Department also has a major responsibility for American Indian reservation communities and for people who live in Island Territories under U. S. administration.

BLM/OR/WA/PT-02/020 + 1792

\author{
BLM Library \\ Denver Federal Center \\ Bldg. 50, OC-521 \\ P.O. Box 25047 \\ Denver, CO 80225
}




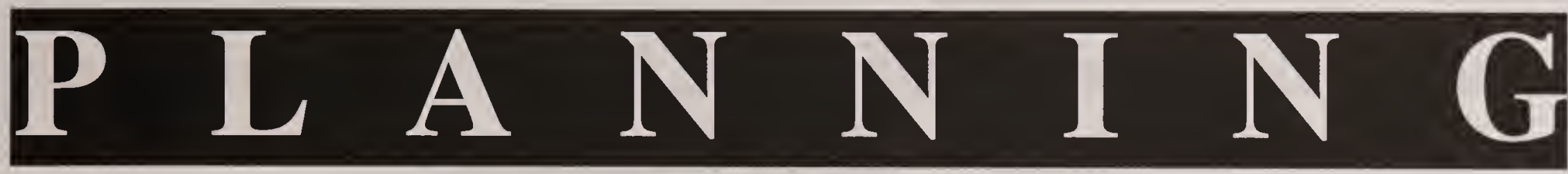

\section{U.S. Department of the Interior Bureau of Land Management}

Burns District Office 28910 Hwy 20 West Hines, Oregon 97738 Web Site: http://www.or.blm.gov/Burns

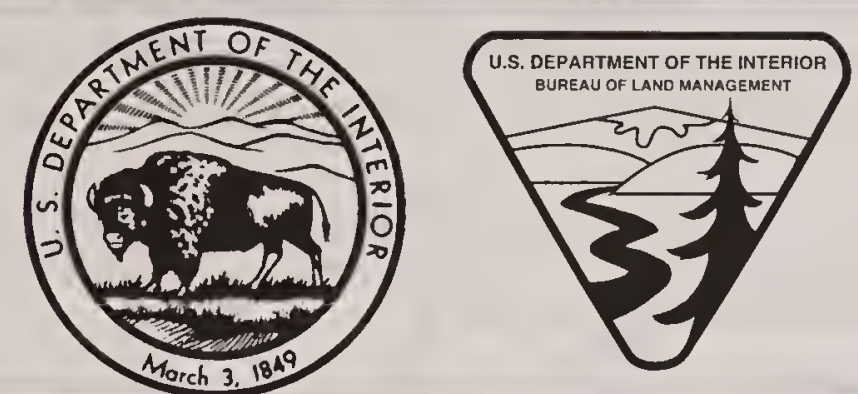
MARCH 2002

\section{Introduction}

This is the tenth annual Planning Update published by the Burns District. Due to extenuating circumstances we were unable to get the Fiscal Year (FY) 01 update completed in a timely fashion. Therefore, we have combined FY01 Planning Update with FY02. This issue reports highlights of FY00 and FY01 accomplishments and work planned for FY02.

It is our desire to keep you informed on issues, activities, and opportunities we think are of interest to our publics. More importantly, we are seeking ideas and comments from those who may be affected by our multiple-use management programs. For general information or for comments regarding the Planning Update, please write to the address shown above.

Please note the change of address. The County has changed all rural addresses to assist the 911 for easier, more rapid location. Please note this change for future correspondence.

\section{What You Can Find In This Document...}

Updates like this one are published annually. While the format is flexible, major sections similar to those described below will be included in each edition.

Summary of Work: This section identifies the fiscal year accomplishments and work proposed for the following year. Usually, only significant work or issues will be discussed. More general information is available to individuals upon request. Page $\underline{5}$

Rangeland Program Summary: This section outlines progress being made in implementing the rangeland management objectives identified in the Resource Areas' (RAs') land use plans.

Page 15

Environmental Assessment (EA) Register: Listed in this section are those EAs expected to be completed this fiscal year. Some may have been identified in the last update, but have not yet been completed. Page 28

EAs and decision documents can also be found on our internet site at http:/www.or.blm.gov/Burns/ Planning/Planning_Index.htm. 


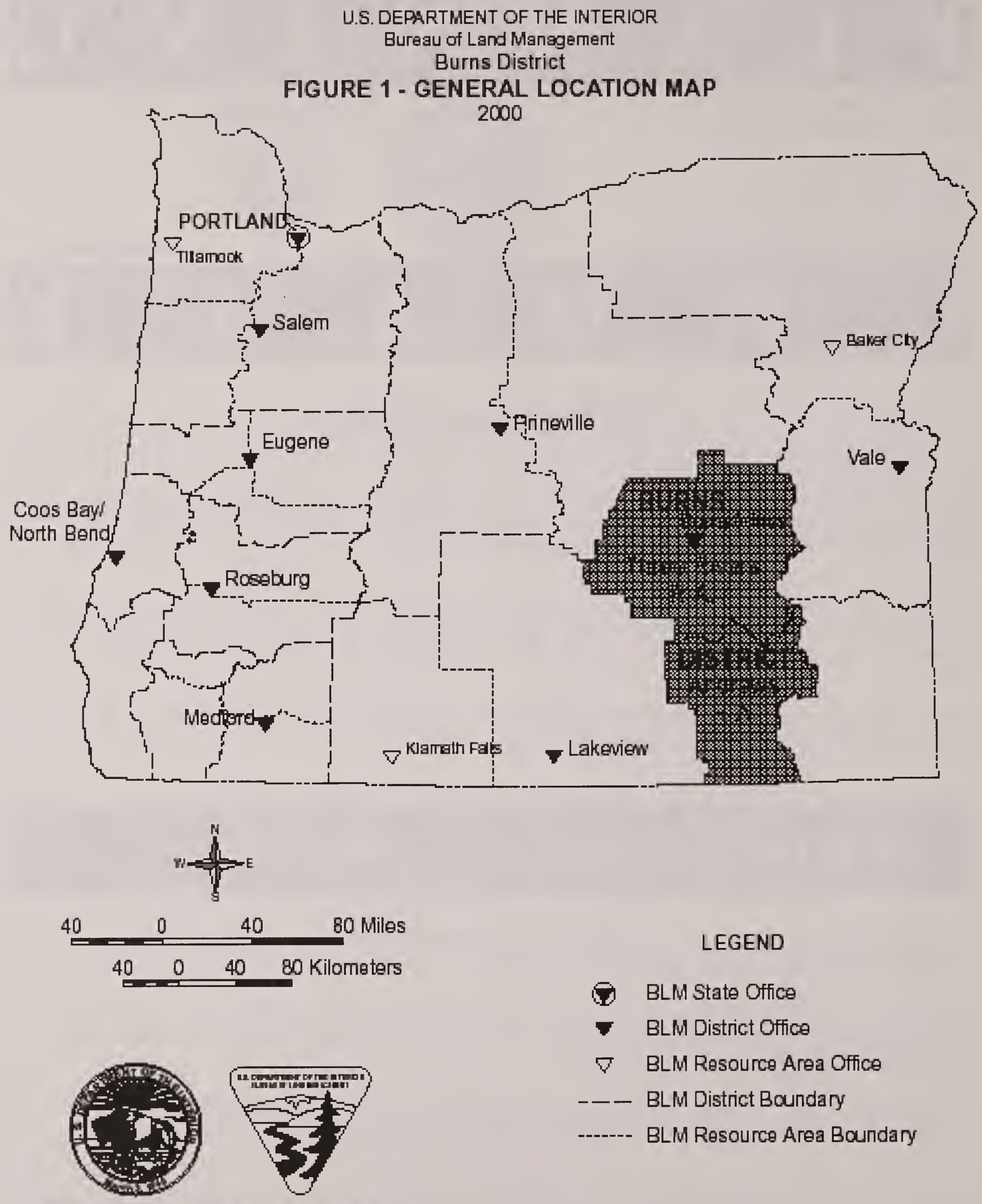

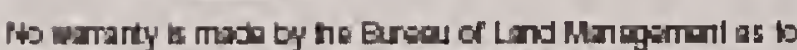

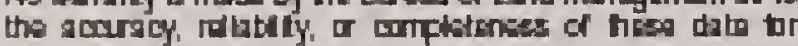

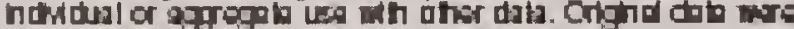

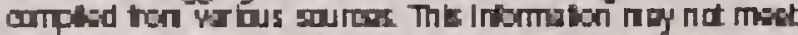

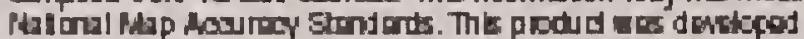
thrugh di gt mars and moy to updast uttoul natlorim. 


\section{Summary of Work Accomplishments and Plans}

This section is not intended to be a comprehensive description of all activities, but rather a summary of significant activities and land use implementation actions, both accomplished and planned. For additional information, please contact the Burns District Office staff.

This summary includes FY00 and FY01 accomplishments with FY02 planned work for the following programs:

Steens Mountain Cooperative Management and Protection Act of 2000*

Prescribed Fire and Fire Management*

Wild Horse and Burro

Recreation

Web Page Update

We have not received our final budget for FY02. Therefore, some of the proposed work may not be completed.

\section{Steens Mountain Cooperative Management and Protection Act of 2000}

\section{Introduction - Summary of Legislation}

The Steens Mountain Cooperative Management and Protection Act (Act) of 2000 was enacted through a bipartisan Congressional effort and created through extensive collaboration among a wide array of local, regional, and National interests. At the heart of the Act is the purpose and process by which to conserve, protect, and manage the long-term ecological integrity of the Steens Mountain Area. This will be accomplished through a collaborative process that fosters cooperative management between the private landowners, local and regional interests, and the Bureau of Land Management (BLM). The Act is unique in its depth of special designations and prescriptions for management direction. Although complex, the Act presents a prime opportunity for the BLM to showcase not just a landscape rich in natural resource diversity, but also its ability to effectively work with the local community, governments, tribal and special interests, and landowners to manage for ecological integrity while providing for traditional uses. Some of the special features of the Act include:

- Establishes a Mineral Withdrawal Area consisting of approximately 900,000 acres of Federal land. These lands are withdrawn from location, entry, and patent under mining laws and operation of mineral leasing, geothermal leasing, and minerals material laws.

- Establishes the Steens Mountain Cooperative Management and Protection Area (CMPA) consisting of 425,550 acres of Federal land and requires a Management Plan to be completed within 4 years after passage of the Act.

- Establishes the Steens Mountain Wilderness Area consisting of 169,465 acres of public land (this includes the legislative acquisition of 13,833 of the 18,632 acres of private land completely surrounded by Congressionally-designated wilderness (see next page). There is a No Livestock Grazing Area with 97,071 acres of public land; the first Congressionallydesignated cattle-free wilderness of its kind. 
- Establishes new Wild and Scenic Rivers to include Kiger Creek (4.25 miles), Wildhorse Creek (7.00 miles), and Little Wildhorse Creek (2.60 miles). It also designates new segments to the Donner und Blitzen Wild and Scenic River as follows: Ankle Creek (8.10 miles), South Fork of Ankle Creek (1.60 miles), and Mud Creek (5.10 miles). These new designations will provide a grand total of 103.65 miles of Wild and Scenic River within the Steens Mountain CMPA. All of these rivers are classified as "wild."

- Establishes the Donner und Blitzen Redband Trout Reserve for the purposes of conserving, protecting, and enhancing redband trout and the unique ecosystem and providing opportunities for research, education, and fish and wildlife-oriented recreation.

- Establishes the 3,267-acre Wildland Juniper Management Area for purposes of experimentation, education, interpretation, and demonstration of management techniques for restoration of a historic fire regime and native vegetation communities.

- Authorizes five specific Land Exchanges to remove private land from within the Wilderness Area and No Livestock Grazing Area (Sections 601 to 605 of Act), and provides for future acquisitions within the boundaries of the CMPA by voluntary exchange, donation, or purchase from willing sellers. The purposes of these acquisitions are to protect and consolidate public ownership within the CMPA.

- Establishes the Steens Mountain Advisory Council (SMAC) to advise the BLM in managing the CMPA and promoting cooperative management. Members of the SMAC have been appointed by the Secretary of the Interior and consist of one private landowner; two grazing permittees; one person interested in fish and recreational fishing; a member of the Burns Paiute Tribe; two persons who are recognized environmental representatives (one local and one Statewide); a person who participates in dispersed recreation such as hiking, camping, horseback riding, etc.; a person who is a recreational permit holder or is a representative of a commercial recreation operation within the CMPA; a person representing consumptive recreation uses such as hunting, fishing, off-road driving, etc.; a person with expertise and interest in wild horse management on Steens Mountain; and one person who has no financial interest in the CMPA to represent Statewide interests.

- Additional provisions provided by the Act which pertain to the CMPA include:

- The use of motorized or mechanical vehicles on public land is prohibited off road, and no new roads shall be constructed with exception for public safety and environmental protection (Section 112 of Act).

- Management shall emphasize the restoration of the historic fire regime and the resulting native vegetation communities through active management of western juniper on a landscape level (Section 113 of Act).

- Hunting and fishing on public land will continue under existing Federal and State authorities (Section 113 of Act).

- New facilities constructed on public land are limited to those that are minimal and consistent with the purposes of the Act, and are for enhancing the botanical, fish, wildlife or watershed conditions; for public information, health or safety; for the management of livestock; or for the management (not promotion) of recreation (Section 113 of Act).

- The BLM may enter into nondevelopment agreements, conservation easements, or conservation incentive payments with willing landowners to further the purposes of the Act (Section 122 of Act).

- The BLM or SMAC may appoint a Science Committee consisting of respected, knowledgeable, and diverse scientists to provide advice on questions relating to the management of the CMPA (Section 133 of Act). 


\section{Actions for this year}

SMAC

The nomination period closed May 4, 2001, with 37 applications received. BLM sent its recommendations along with those of the Harney County Court, the Governor's Office and the Burns Paiute Tribe to the Secretary of the Interior for approval in July. The appointments were announced by the Secretary on August 14, 2001. The first meeting was held on October 22 and 23, in Hines, Oregon.

\section{No Livestock Grazing Area - Projects, Status}

An EA for "Projects for Implementation of the Steens Mountain Cooperative Management and Protection Act (EA OR-027-01-27)" was written, circulated for public comment, and approved with no appeals.

The projects in this EA are needed to implement the "No Livestock Grazing Area" described in the Act, install and maintain fencing required for resource protection within this area, provide replacement forage within and outside the CMPA, and construct fencing and water systems to allow for sustainable livestock grazing which promotes the long-term ecological integrity within the CMPA.

The proposed projects include construction of approximately 25 miles of new fence, four cattleguards, drilling of two wells, installing approximately 13 miles of pipeline with 13 water troughs, constructing eight new waterholes, developing three springs, and conducting maintenance on two additional springs. Also proposed is removal of approximately 55 miles of unnecessary fence which exists throughout the No Livestock Grazing Area and Steens Mountain Wilderness.

\section{Wilderness - Signing Boundaries}

The Steens Mountain Wilderness was designated with the signing of the Act. The Steens Mountain Wilderness is now a component of the National Wilderness Preservation System. All motorized and mechanized equipment are prohibited in wilderness except as provided for in the Act. Wilderness boundaries will be signed as closed to motorized and mechanized equipment to comply with wilderness regulations. Boundary signing is approximately 85 percent complete.

\section{Land Exchanges}

Approximately 18,259 acres are proposed for acquisition through legislated exchanges mandated by the Act. The purposes of the exchanges are to protect and consolidate public land within the CMPA and to remove private land within the Steens Mountain Wilderness and No Livestock Grazing Area. To date, three of the five legislated exchanges have been completed and the remaining two should be completed by the end of FY02.

\section{CMPA Dedication}

A dedication and awards ceremony was held on August 14, 2001 at the BLM, Burns District Office Page Springs Campground. The dedication commemorated the partnership of public and private efforts to protect the cultural, economic, and ecological values of one of Oregon's natural treasures, Steens Mountain. The ceremony was attended by approximately 300 people. Special guest speakers included Albert Teeman of the Burns Paiute Tribe. 
Congressman Greg Walden, Senators Ron Wyden and Gordon Smith, Mike Carrier from the Governor's Office, Judge Steve Grasty, Jill Workman of the Steens Alvord Coalition, Roaring Springs Ranch Manager Stacy Davies, and Acting BLM Director Nina Hatfield. Hatfield presented a framed and matted photo of Kiger Gorge to Lindsay Slater. Slater was awarded for his efforts during the development of the Act. Other participants in the program were Oregon's Army National Guard, Marie Jarreau-Danner of the Burns Times-Herald, members of the Burns Paiute Tribe and two local students. Master of Ceremonies was Burns District Manager Tom Dyer. Congress recognized the Steens Mountain CMPA, located in Harney County, Oregon, fosters exceptional cooperative management opportunities and offers outstanding natural, cultural, scenic, wilderness, and recreational resources. To ensure those resources are appropriately managed, the Act mandated the Oregon BLM, Burns District, to prepare a management plan for the CMPA by October 30, 2004.

\section{Andrews Resource Area Resource Management Plan}

In 1995, preparation of the Southeastern Oregon Resource Management Plan (SEORMP) was initiated by the BLM, Vale and Burns District Offices. The SEORMP initially included the Burns District Andrews RA. As a result of the Act, however, it was determined a separate RMP for Andrews RA and Steens CMPA to address changes in management resulting from directives of the Act should be written. Consequently, Andrews RA is no longer addressed in the SEORMP. As required by the National Environmental Policy Act (NEPA), an Environmental Impact Statement (EIS) will be written to analyze alternatives posed in the Andrews/ Steens RMP.

Congress recognized the Steens Mountain CMPA, located in Harney County, Oregon, fosters exceptional cooperative management opportunities and offers outstanding natural, cultural, scenic, wilderness, and recreational resources. To ensure those resources are appropriately managed, the Act mandated the Oregon BLM, Burns District, to prepare a management plan for the CMPA by October 30, 2004.

The area to be addressed in the RMP/EIS involves the Andrews RA, including the CMPA, and a small segment of the Burns District Three Rivers RA included in the CMPA.

The RMP process was initiated in September 2001, with the hiring of a contractor, Environmental and Resource management (ERM), to write the RMP/EIS. ERM's first assignment is to complete the Analysis of the Management Situation and Subbasin Review by the end of December 2001. Public scoping is scheduled to begin in February 2002, with the draft RMP/ EIS available in August 2003.

\section{Prescribed Fire}

The Burns District of the BLM manages a diverse landscape in the Southern Blue Mountains and Northern Great Basin of southeastern Oregon. In the northern end of the District ponderosa pine is the dominant species, and in the southern end sagebrush is the most obvious plant species. Both of these areas have undergone drastic changes over the last 120 years. Past management actions in response to social concerns have directed the BLM and other Federal agencies to protect this land from fire. These aggressive fire suppression actions achieved the management goal of protecting the land from fire. However, these actions have also increased the risk of large fires. Fires were a historic component of most of the plant communities within the Burns District, and removal of that component has caused a widespread build of live and dead plant material. This living and dead plant material, or fuel load, is well in excess of historic levels. Today, fires that occur burn at a greater intensity over a potentially larger area. Recent and future work by the Burns District in the ponderosa pine forest and sagebrush-steppe are directed to reduce the hazardous levels of fuel and restore native plant and animal communities. 


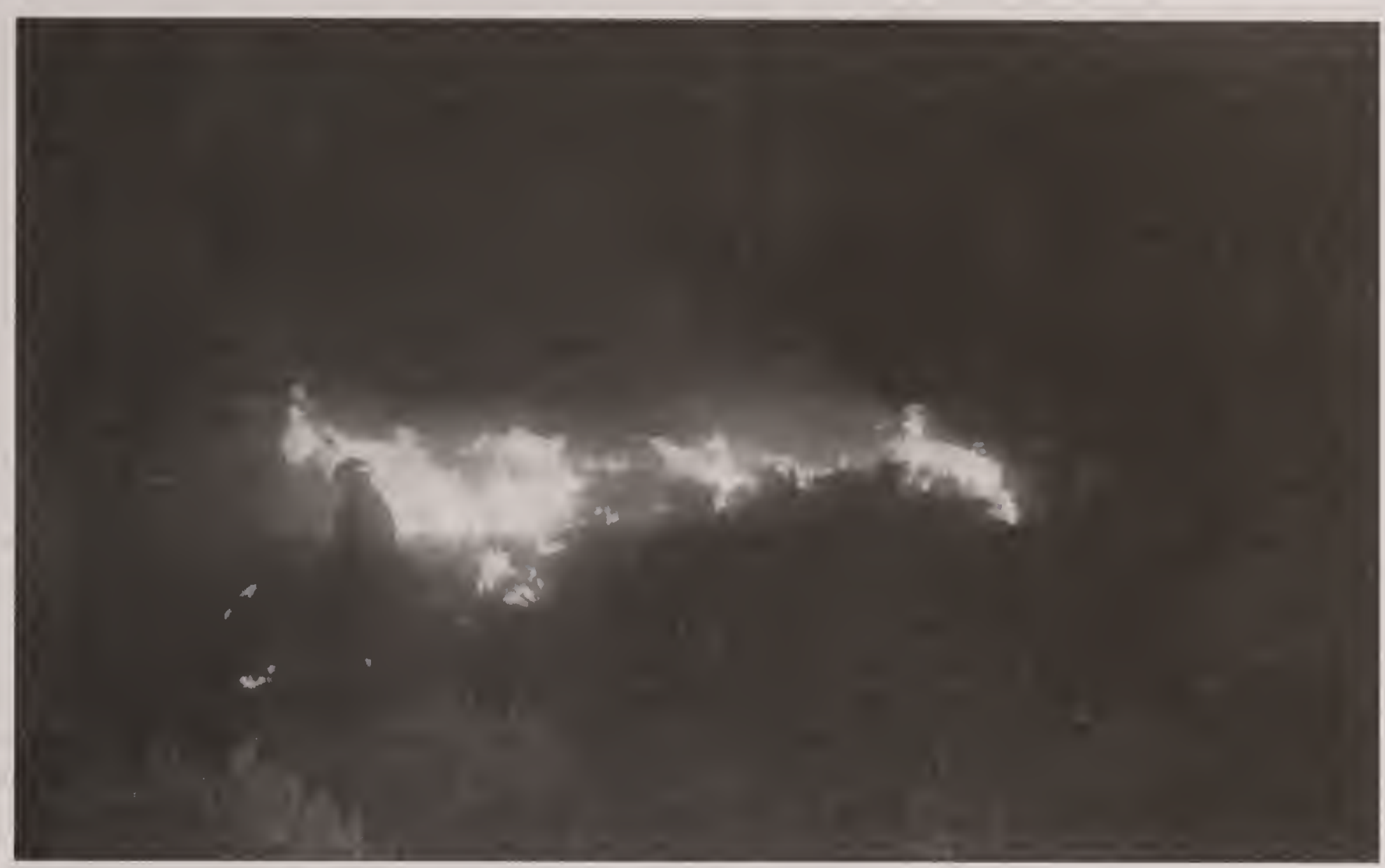

Prescribed fire - Steens Mountain - photo by Jeff Rose.

The encroachment of western juniper into the more productive sagebrush-grassland of the Northern Great Basin presents land managers with an interesting challenge. As density and cover of these trees increases, cover and density of associated understory vegetation decreases. There is also an increase in bare ground with the decrease in the understory vegetation. The structure of the plant community changes from a shrub-steppe with a diverse plant and animal community to a structurally simplistic woodland that provides habitat for fewer plants and animals.

In the spring of 2001 , the Burns District treated just over 800 acres of the ponderosa pine forest. The Blackrock Prescribed Fire conducted in May was conducted jointly with the Forest Service (FS) to reduce the amount of fuel present and thin the stand to increase vigor of the rest of the trees. Early monitoring results indicate that the project achieved the project goals.

The V-Lake, East Ridge, and Stonehouse projects on the Steens Mountain treated just over 27,000 acres of mountain big sagebrush and western juniper woodlands. All three projects were cooperative projects with neighboring private landowners. The three projects used a combination of mechanical and prescribed fire treatments on a landscape level. Cooperation of the adjacent private landowners allowed the prescribed fires to utilize natural barriers, reducing the amount of mechanical and hand constructed fireline and keeps the total cost of the project down.

In the late summer or early fall of 2002 , three prescribed fires are scheduled. The Burns District will finish the Stonehouse project burning approximately 6,000 acres of public and private lands. The second phase of the East Ridge project will also begin and Chimney/ Tackman prescribed fire will occur. All of these projects will help to reduce the dominance of western juniper and reintroduce fire to the mountain big sagebrush plant community and create a complex mosaic of burned and unburned areas. The Stonehouse, East Ridge, and Chimney/Tackman projects will also treat aspen stands that have been severely degraded by western juniper encroachment. 
Selected stands will be fenced to protect the new aspen suckers from browsing by domestic and wild herbivores. These fences will be removed after aspen suckers are tall enough that apical meristematic tissue are above the browse line.

\section{Wildfire Rehabilitation}

The Burns Interagency Fire Zone, comprised of the Burns District of the BLM, Emigrant Creek Ranger District of the Malheur National Forest, and the Oregon Department of Forestry, had one of its busiest fire seasons in recent years. The fire zone initial attacked 219 fires that burned 65,500 acres. However, three of those fires totaled just over 60,000 acres.

The Big Stick Fire was ignited by lightning in the late afternoon on July 4. This fire burned 9,600 acres of Wyoming and basin big sagebrush plant communities. Seven days later lightning ignited the Double O Fire which grew to approximately 1,800 acres. A joint fire rehabilitation plan was developed for these two fires. The main goal of the rehabilitation plan was to reestablish perennial plant species throughout the two burned areas. Cheatgrass has made a significant inroad in the plant communities and almost totally dominated the Double O Fire plant communities. There was also an effort to reestablish woody plants in both these areas. The size of the fires and limited dispersal distance of sagebrush seed probably would increase the time until sagebrush become prominent in the plant communities. This has a significant influence on many wildlife species that depend on sagebrush for either part or all of their life cycle. Hopefully, planting sagebrush and rabbitbrush will help reduce the time needed for woody plants to establish.

Four fires were discovered in the Steens Mountain Wilderness Area. The two largest fires were 10 and 270 acres. The other two fires were less than 5 acres and extinguished with very minimal action by the BLM. The two larger fires required more intensive action because of their proximity to the South Steens Campground. Minimal impact suppression tactics were employed on these two fires. Suppression action will continue until a Wildland Fire Use Plan can be developed after the completion of the Andrews/Steens RMP. However, an interim fire management plan has been developed and approved and all suppression actions will utilize the minimum tool policy.

\section{Noxious Weed Program}

During 2000 and 2001, the District Integrated Weed Management Program actively participated in the ongoing Harney County Weed Management Partnership. This partnership tries to focus and coordinate the management of noxious weeds throughout all the area agencies. These include Harney County Weed Control, Oregon Department of Agriculture, BLM, FS, Malheur National Wildlife Refuge, Agriculture Research Service Experiment Station, Oregon Department of Transportation (ODOT), the cities of Burns and Hines, Soil and Water Conservation District (SWCD), Oregon Department of Fish and Wildlife (ODFW), and Oregon State University (OSU) Extension. Activities conducted throughout the year include Education/Awareness Trainings for agency staff and the public, both formal and informal; coordinated inventory and monitoring; coordinated control efforts including cost-share opportunities; and coordinated research and demonstration projects and plots. This Partnership has proven to be a very effective way to conduct weed management in our area and is anticipated to continue through FY02 and beyond.

Highlights of the Partnership in FY01 include:

* Acquisition and outfitting of our new Weed Awareness Mobile: a 25-foot-long office trailer decked out as a complete walk-through Weed Experience! 
* Continued development of a Statewide Weed Curriculum for grades K-12.

* Aerial (helicopter) inventory of 87,000 acres of checkerboard BLM and private lands, most notably looking for dalmatian toadflax.

* Acquisition of $\$ 25,000$ in grant money for the County Cost Share program, which will facilitate projects in areas of cooperative weed control projects.

* Initiation of several cooperative research projects: a) to quantify impacts of various herbicides for medusahead control on associated vegetation, particularly forbs; b) to evaluate livestock grazing treatments for perennial pepperweed management; and c) continuing research evaluating plant species for road rights-of-way revegetation.

* Demonstration plots for evaluating control methods for Russian knapweed and dalmatian toadflax.

* Several coordinated control projects throughout the County including road rights-ofway and areas of mixed ownership.

The following weed program activities occurred on the Burns District:

\section{FY00 -}

79,000 acres inventoried, including extensive inventories of previous year wildfires

1,200 acres of treatments applied, including both manual and chemical controls (hand application)

Approximately 640 acres of treatments were evaluated

\section{FY01 -}

107,560 acres inventoried - including 68 miles of BLM-maintained roads in remote areas of the Andrews RA

1,349 acres of treatments applied, both manual and chemical controls. Benefits of treatments accomplished include 4 miles of riparian habitat and 615 acres of wetland habitat.

Approximately 2,620 acres of treatments were evaluated.

Weed management plans for FY02 include approximately 1,200 acres of treatment, 50,000 acres of inventory, and 1,500 acres of treatments evaluated.

\section{Wild Horse and Burro Program}

The Burns District is the lead office for Oregon and Washington's wild horse adoption and gathering program. The District manages eight wild horse Herd Management Areas (HMAs) and provides support for the management of 11 others that are located in the Lakeview, Vale, and Prineville Districts. In addition, one herd is managed by the Ochoco National Forest near Prineville and a second near Dayville is managed jointly by the Prineville District and the Malheur National Forest.

Currently, approximately 2,750 horses are on the range in Oregon's 21 HMAs. Horse numbers increase annually at a rate of 18 to 20 percent. Each herd is gathered every 3 to 5 
years, depending on range conditions and actual population numbers, which are determined by range studies and periodic census.

Since the 2000 planning update, the Burns District removed 69 horses from the Alvord-Tule Springs HMA (January 2001); and 325 horses from the Warm Springs HMA (September 2001). These animals and 823 other horses gathered in the Lakeview and Vale Districts were delivered to the Burns Wild Horse Corrals, and were made available to the public through the Wild Horse Adoption Program.

During the next year, the Burns District plans to remove approximately 34 horses from the Heath Creek-Sheepshead HMA. Another 745 head are planned for removal from other districts in Oregon.

Oregon's wild horses are known nationally for their quality and color, and are very popular with the Nation's adopters. Each of Oregon's herds have their own unique characteristics. Some examples are the South Steens pintos, Hog Creek and Palomino Butte palominos, Warm Springs Appaloosas, Stinkingwater horses with draft blood, and the highly sought after Kiger Mustangs in the Kiger and Riddle HMAs.

Gathered excess animals are available to qualified adopters through adoption events held at the Burns Wild Horse Corrals and in cities throughout Oregon and Washington. Burros from the southwest are also available at some Oregon adoption events. Eight adoption events were held in 2000 and ten were held in 2001. In 2000, 373 horses and burros were adopted in Oregon and Washington, while other animals were transported to other states for adoption. In 2001, 492 horses were adopted.

BLM is now using competitive bidding to establish adoption fees. Competitive bidding replaces the lottery method used in past years. Through the lottery method, adopters had to rely on "the luck of the draw" for horse selection. Competitive bidding allows all animals to be available to all adopters present, with animals adopted to the highest bidders. The average adoption fee during the past year for Oregon events was about $\$ 190$ per animal.

Wild horse gentling demonstrations are held at most adoption events. These demonstrations not only provide adopters an opportunity to learn about a variety of gentling and training techniques, but also generate a lot of interest in the adoption program.

Burns District is responsible for coordinating 7 to 10 adoption events that are held at various cities in Oregon and Washington.

Animals are also available to adopters through "Walk Up" appointments at the Burns Corrals for the minimum adoption fee of $\$ 125$ per animal.

Horse enthusiasts are finding that wild horses have a place among America's horses, and they perform admirably in a variety of situations. Adopters report that the gentling process is occasionally challenging, but always rewarding. Wild horses are commonly used for pleasure and trail animals, packing, ranch work, and occasionally in competitive events. They are known for their intelligence, endurance, and agility.

Information about the Wild Horse Program is available through the internet at the following sites:

National Wild Horse and Burro Web Page: http://www.blm.gov/whb

Burns District Home Page: http://www.or.blm.gov/Burns/

burns_wild_horses_and_burros.htm

Adoption applications and information may also be obtained by calling the Burns District Office at (541) 573-4456. 


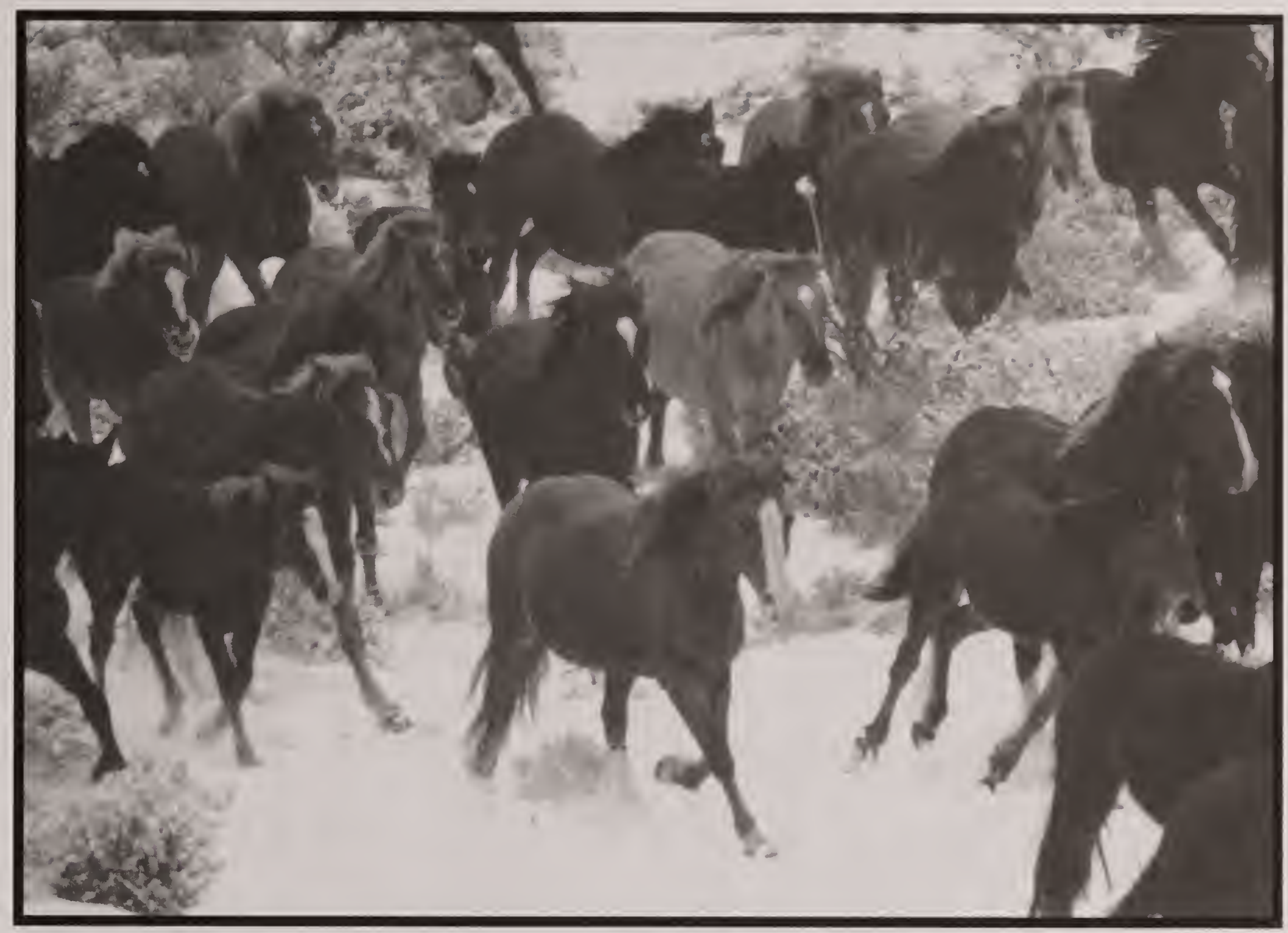

Coyote Lake Area - Photo by Dean Bolstad

\section{District Recreation Program}

Last year and continuing this year, we have focused on needed improvements at several popular recreational fishing sites.

In 1999, the Poison Creek Dam was constructed in Silvies Valley approximately 1-mile from U.S. Hwy 395 and FS Road 17. This year the access road and parking area will be graveled and a vault toilet installed. The reservoir has partially filled, and will be stocked with trout by ODFW in the future.

The improvements started at Chickahominy Recreation Site in FY00 are continuing this year. This is a cooperative project with BLM, ODFW, and Harney County. Two miles of access road with turnouts, and parking areas at favorite fishing points have been graveled. Last year. and continuing this year is rehabilitation of the shoreline. Over 8 miles of two-track roads were ripped and reseeded, with construction of fence and placing of boulders and gates to close areas to vehicles.

This year we plan to work with the County to "spot" gravel and place culverts in the Warm Springs access road and riprap the boat ramp to prevent further deterioration.

Approximately 3 miles of the Moon Reservoir access road was graveled this year for recreation access. 


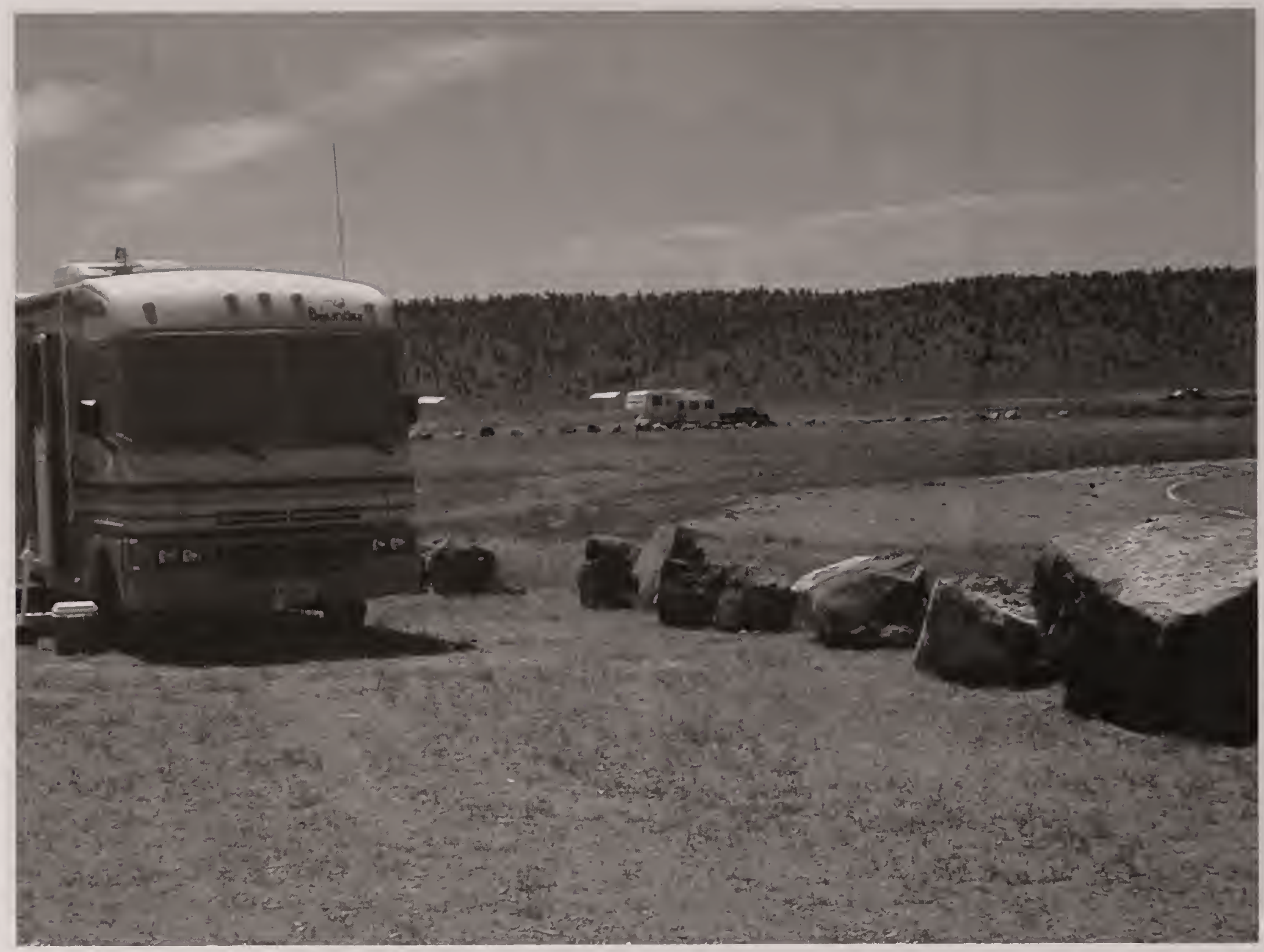

Chickahominy Recreation Site - Photo by Fred McDonald

\section{Web Page Update}

The Burns District Office has upgraded the Internet web site at http://www.or.blm.gov/Burns to include new pages on the District Planning and EA Program.

In addition to the Burns District web site, we also maintain the Southeast Oregon Resource Advisory Council (SEORAC or RAC) web site at http://www.or.blm.gov/SEOR-RAC. This web site provides the RAC's mission, jurisdictional boundary and map, list of council members, news releases, Federal Register notices, and the meeting minutes for public review. The RAC provides representative citizen counsel and advice to the Secretaries of the Interior and Agriculture through the BLM and FS concerning the planning and management of the public land and National forest resources located in whole or in part within the Burns, Vale, and Lakeview Districts of the BLM and the Fremont, Deschutes, Ochoco, and Malheur National Forests.

The Burns District developed a new web site located at http://www.or.blm.gov/steens. This web site is dedicated to the Steens Mountain CMPA. The site provides information on the legislation, maps, area links, directory, and a nice photo gallery. 


\title{
Burns District Rangeland Program Summary
}

\author{
Introduction
}

The purpose of the Rangeland Program Summary (RPS) Update is to outline the progress being made in implementing the rangeland management objectives of each Resource Area as identified in the current land use plans.

\section{Interested Publics}

Following issuance of this RPS Update, there will be a 30-day comment period for the public to request affected interest status. If you believe that any of the future actions indicated in the RPS Update may affect your interests, contact the BLM Burns District Manager in writing by May 18, 2002. You must advise which specific future actions concern you, the allotment or allotment(s) involved, and your reason for believing that you have an interest that can be affected by future actions. The District Manager will provide those determined to have an affected interest with an opportunity to participate in the development of the livestock grazing management plans in the identified allotments.

\section{Three Rivers Resource Area}

\section{New Allotment Numbers}

In anticipation of implementing a new grazing billing system in FY01, several allotment numbers were changed throughout the State to ensure that each allotment has a unique number. The following allotment number changes have been made.

$\begin{array}{lcc}\text { Allotment Name } & \text { Old Number } & \text { New Number } \\ \text { Beaver Creek } & 5213 & 5600 \\ \text { Beckley Home } & 5211 & 5598 \\ \text { Burnt Flat } & 5313 & 5604 \\ \text { Catterson FFR } & 5203 & 5586 \\ \text { Coleman Creek } & 5201 & 5592 \\ \text { Coyote Creek } & 5207 & 5595 \\ \text { Crane } & 5209 & 5597 \\ \text { Emmerson } & 5208 & 5596 \\ \text { Hamilton } & 5214 & 5601 \\ \text { Mahon Ranch } & 5212 & 5599 \\ \text { Manning Field } & 5107 & 5587 \\ \text { Quier FFR } & 5216 & 5602 \\ \text { Rattlesnake FFR } & 5113 & 5591 \\ \text { Reed FFR } & 5110 & 5588 \\ \text { Slocum } & 5204 & 5593 \\ \text { Smith FFR } & 5112 & 5590 \\ \text { Temple's FFR } & 5111 & 5589 \\ \text { Venator } & 5205 & 5594 \\ \text { Virginia Valley FFR } & 5311 & 5603\end{array}$




\section{FY 2002 Plans}

During FY02, the monitoring data will be analyzed, interpreted, and evaluated to document the progress of management to meet resource objectives for the following allotments. An assessment of Standards for Rangeland Health will be included in the evaluation.

$\begin{array}{lclr}\text { Allotment Name } & \text { Allotment Number } & \text { Allotment Name } & \text { Allotment Nu } \\ \text { Cow Creek } & 5106 & \text { Griffin } & 5548 \\ \text { Princeton } & 5301 & \text { Wheeler Basin } & 5564 \\ \text { Smyth-Kiger } & 5331 & \text { Lamb Ranch } & 5571 \\ \text { Muddy Creek } & 5506 & \text { School House } & 5575 \\ \text { Clarks River } & 5512 & \text { Lower Pine } & 5576 \\ \text { Shelley } & 5513 & \text { Slocum } & 5593 \\ \text { Mule Creek } & 5515 & \text { Crane } & 5597 \\ \text { Birch Creek } & 5516 & \text { East Warm Springs } & 7001 \\ \text { Mahon Cree } & 5534 & \text { West Warm Springs } & 7002 \\ \text { Alder Creek } & 5536 & \text { West Wagontire } & 7004 \\ \text { Riverside } & 5538 & \text { Sand Hollow } & 7020 \\ \text { Sunshine Field } & 5545 & \text { Silvies River } & 7033 \\ \text { Lake Field } & 5547 & \text { Silvies Canyon } & 7053\end{array}$

Allotment Management Plans (AMPs) will be developed or revised for the following allotments:

Lime Kiln

Soldier Creek 5104

Cow Creek 5106

House Butte 5529

Venator 5594

Crane 5597

Hamilton 5601

West Warm Springs 7002

Palomino Butte 7019

Hayes $\quad 7036$

\section{Grazing Permit/Lease Renewals}

Grazing permits or leases are scheduled to expire between February 28, 2002 and September 30,2006 , in the following allotments. Allotments are listed if the permit/lease for any permittee is expiring. There may be other permittees in an allotment whose permits or leases are not expiring. The required National Environmental Policy Act (NEPA) analysis will be prepared prior to renewal of these permits. There were 10 permits reissued in FY01.

Allotments with permits expiring in 2002 are:

$\begin{array}{lll}\text { \#5301 - Princeton } & \text { \#5515 - Mule Creek } & \text { \#5536 - Alder Creek } \\ \text { \#5302 - Big Bird } & \text { \#5516 - Birch Creek } & \text { \#5542 - Marshall FFR } \\ \text { \#5316 - Virginia Valley } & \text { \#5517 - Otis Mountain } & \text { \#5544 - Brooks Field } \\ \text { \#5317 - Hatt Butte } & \text { \#5519 - Big Upson } & \text { \#5545 - Sunshine Field } \\ \text { \#5322 - Briggs' FFR } & \text { \#5522 - Cottonwood Creek } & \text { \#5547 - Lake Field } \\ \text { \#5325 - Marshall Diamond } & \text { \#5523 - Tub Springs/Hart } & \text { \#5549 - Howard's FFR } \\ \text { \#5505 - Little Muddy Creek } & \text { \#5525 - Mill Gulch } & \text { \#5550 - Jordan's FFR } \\ \text { \#5507 - Wolf Creek } & \text { \#5526 - Chalk Hills } & \text { \#5554 - J. Francis Miller FFR } \\ \text { \#5508 - Baker-Knowles } & \text { \#5528 - Cooler } & \text { \#5564 - Wheeler Basin } \\ \text { \#5511 - Moffet Table } & \text { \#5529 - House Butte } & \text { \#5565 - Upton Mountain }\end{array}$


\#5575 - Schoolhouse

\#5587 - Manning Field

\#5590 - Smith FFR

\#5598 - Beckley Home

\#7003 - East Wagontire
\#7006 - Rimrock Lake \#7010 - Claw Creek \#7021 - Weaver Lake \#7022 - Dog Mountain \#7026 - Horton Mill

Allotments with permits expiring in 2003 are:

\#5101 - Devine Ridge
\#5105 - Camp Harney
\#5106 - Cow Creek
\#5221 - West Davies
\#5223 - East Davies
\#5301 - Princeton
\#5306 - Rocky Ford
\#5316 - Virginia Valley
\#5325 - Marshall Diamond
\#5502 - Rock Creek

\#5101 - Devine Ridge

\#5105 - Camp Harney

\#5223 - East Davies

\#5306 - Rocky Ford

\#5325 - Marshall Diamond

\#5502 - Rock Creek
\#7028 - Stinger Creek \#7038 - Curry Gordon \#7061 - Bulger \#7062 - Capehart Lake

Allotments with permits expiring in 2004 are:
\#4126 - Abraham's Draw \#5507 - Little Muddy Creek \#5524 - Dawson Butte \#5529 - House Butte \#5532 - Mountain \#5535 - Miller Canyon \#5539 - W\&C Blaylock FFR \#5600 - Beaver Creek \#5540 - Luce Field \#5543 - Devine Flat Field
\#5546 - Druitt Field and FFR \#5551 - Lillard's FFR \#5552 - Miller FFR A \#5553 - Miller FFR B \#5560 - Vickers' FFR \#5571 - Lamb Ranch \#7002 - West Warm Springs \#7005 - Second Flat

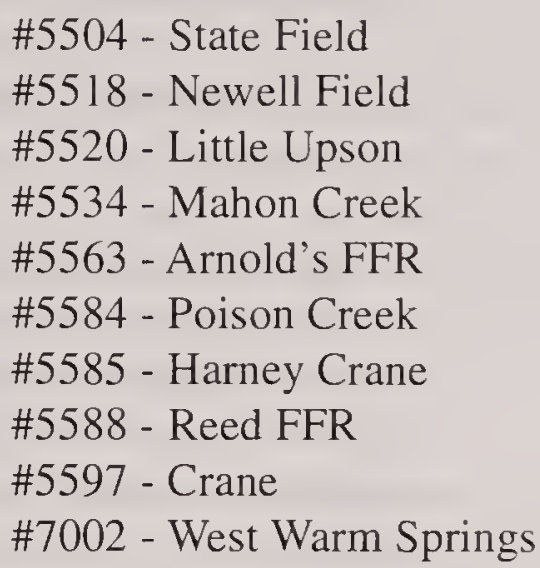

\#7007 - Hat Butte \#7026 - Horton Mill \#7028 - Stinger Creek \#7029 - Spring Creek \#7030 - Skull Creek \#7034 - Scat Field \#7036 - Hayes \#7043 - Lone Pine \#7049 - Forks of Poison Creek \#7052 - Lone Pine Fields

Allotments with permits expiring in 2005 are:

\#4138 - White
\#5202 - Hunter
\#5203 - Catterson
\#5303 - Dry Lake
\#5503 - Pine Creek
\#5512 - Clark's River
\#5529 - House Butte
\#5532 - Mountain
\#5537 - Buck Mountain

\#4138 - White

\#5303 - Dry Lake

\#5503 - Pine Creek

\#5529 - House Butte

\#5537 - Buck Mountain

Allotments with permits expiring in 2006 are:

\#5003 - Malheur Slough \#5101 - Devine Ridge \#5102 - Prather Creek \#5217 - Thompson FFR \#5218 - Bennett FFR \#5301 - Princeton \#5306 - Rocky Ford \#5309 - Happy Valley \#5310 - Riddle Mountain \#5316 - Virginia Valley \#5323 - Clemens' FFR \#5324 - Riddle FFR \#5326 - Jenkins' N. Lake \#5327 - Jenkins' B. Flat \#5328 - Fisher FFR

\author{
\#5556 - Pine Creek FFR \\ \#5566 - Texaco Basin \\ \#5593 - Slocum \\ \#7001 - East Warm Springs \\ \#7004 - West Wagontire \\ \#7009 - Dry Lake \\ \#7016 - Juniper Ridge \\ \#7025 - Gouldin \\ \#7030 - Skull Creek
}

\#5330 - Barnes Well \#5331 - Smyth-Kiger \#5510 - Jones Dripp \#5511 - Moffet Table \#5513 - Shelley \#5514 - Coal Mine Creek \#5527 - Riverside FFR \#5532 - Mountain \#5533 - Buchanan \#5536 - Alder Creek \#5537 - Buck Mountain \#5538 - Riverside \#5548 - Griffin FFR \#5559 - Sword's FFR
\#7019 - Palomino Buttes \#7023 - West Sagehen \#7024 - East Sagehen \#7026 - Horton Mill \#7033 - Silvies River \#7040 - Landing Creek \#7046 - Baker Hill

\author{
\#7032 - Hotchkiss \\ \#7043 - Lone Pine \\ \#7044 - Cowing \\ \#7047 - Peabody \\ \#7048 - Varien Canyon \\ \#7049 - Forks of Poison Creek \\ \#7051 - Sawtooth MNF \\ \#7059 - Carp \\ \#7063 - Roundtop Butte
}

\#5561 - Wilber FFR \#5568 - Byron's FFR \#4473 - Beaver FFR \#5577 - Cooper Field FFR \#5586 - Catterson Sec. 13 \#5589 - Temple FFR \#5595 - Coyote Creek \#5596 - Emmerson \#5599 - Mahon Ranch \#5601 - Hamilton \#5604 - Burnt Flat \#7043 - Lone Pine re \#7045 - Whiting 


\title{
FY00 and 01 Accomplishments
}

\author{
Allotment Allotment \\ Number Name Category* Implementation Progress
}

*I = Improve; $\mathbf{M}=$ Maintain; $\mathbf{C}=$ Custodial

4097 Trout Creek I Two reservoirs were constructed in this allotment to improve livestock distribution and draw livestock away from riparian areas.

4143 Silvies

5101 Devine Ridge
Two and one-half miles of boundary fence between the BLM and the FS were reconstructed.

An allotment management evaluation was conducted to analyze, interpret, and evaluate whether or not present management is meeting resource objectives. Results indicate that the grazing system outlined in the AMP has not been followed consistently; however, the grazing treatments have been meeting objectives in two of the pastures. Utilization levels have been too high in the third pasture. Forage production overall in the allotment is sufficient to meet forage demand. The assessment of Standards for Rangeland Health found that the standards for upland watershed function and ecological processes were being met. The standards for riparian watershed function, water quality, and native species were not met; however, the determination was that livestock was not a significant factor. The evaluation recommends limiting early spring use to keep utilization levels within management limits. It is recommended that the selective management category be changed to 'I.'

The AMP was revised to incorporate the recommendations from the allotment management evaluation and address the conflicts and concerns identified in the Three Rivers RMP. The conflicts and concerns include water quality, erosion, riparian and aquatic habitat, and Special Status species. The objectives developed for the AMP are to:

-maintain all seral stages in current status to provide a diversity of habitat types, conditions and forage requirements in all of the pastures during the next four grazing cycles,

-maintain habitats for Special Status species: bald eagle (winter roosts), sage grouse (brood rearing), redband trout and Malheur mottled sculpin (yearround life cycle),

-cause an upward (improve) trend in the fair condition riparian habitat in Coffeepot Creek and Mill Creek and maintain the good riparian conditions along Rattlesnake Creek during the next four grazing cycles.

A grazing system has been designed which will meet these objectives. Key forage species and utilization levels have been identified for each pasture.

The AMP was revised to incorporate the recommendations from the allotment management evaluation. The objective developed for the AMP is to:

-maintain mid and late seral stage range conditions in the stiff sagebrush, low sagebrush, and mountain big sagebrush range sites across the allotment.

A grazing system has been designed which will meet this objective. Key forage species and utilization levels have been identified for the allotment.

An allotment management evaluation was conducted to analyze, interpret, and evaluate whether or not present management is meeting resource objectives. 


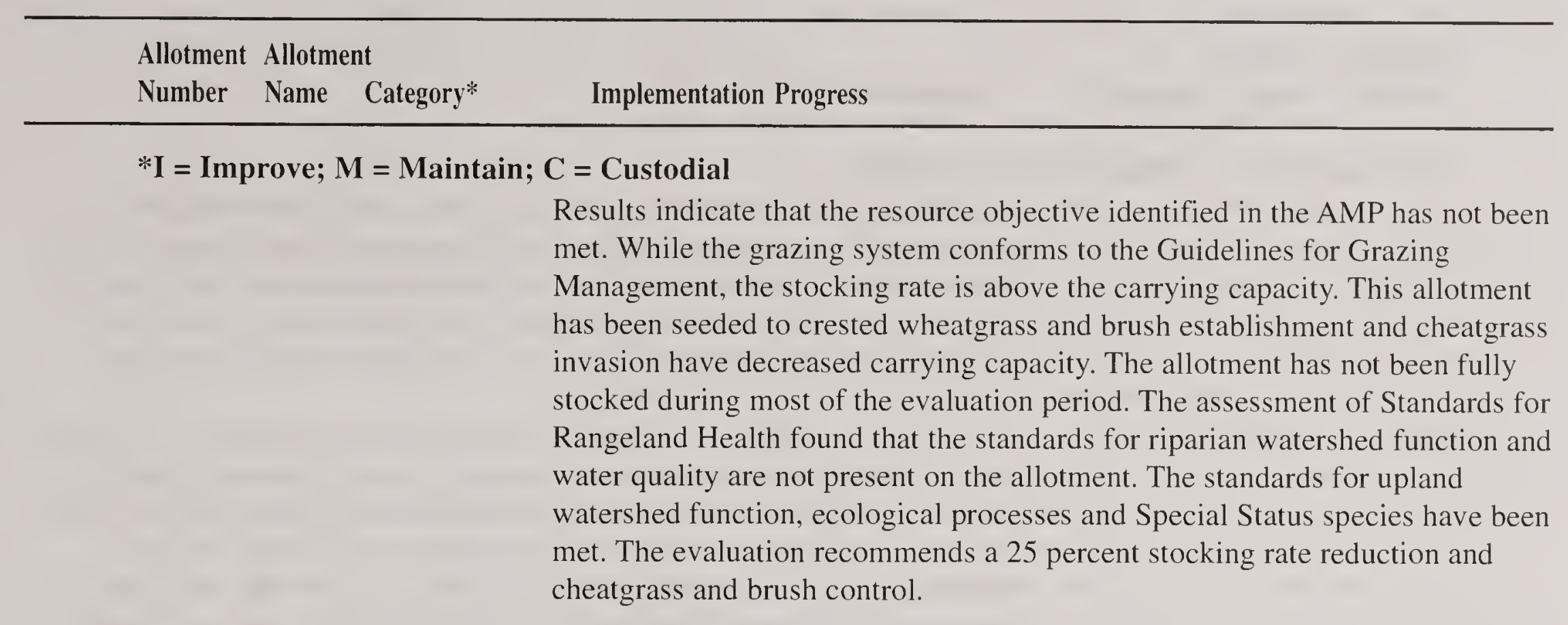

\section{Riddle I Mountain}

5503 Pine Creek I

5511 Moffet Table

I 5514 Coal Mine I
Creek

\section{House Butte I}

5596 Emmerson

\begin{abstract}
A reservoir was constructed to improve livestock distribution. Two aspen groves were rejuvenated by having the junipers removed and protective fencing installed to allow for establishment of new aspen trees.
\end{abstract}

Western junipers were cut from 46 acres to reduce competition with other vegetation and improve rangeland condition.

A prescribed fire was conducted in the fall of 2000 to reduce western juniper in a mountain big sagebrush type. The juniper reduction will enhance big game habitat and improve vigor of other vegetation. Approximately 1,100 acres were burned.

An allotment management evaluation was conducted to analyze, interpret, and evaluate whether or not present management is meeting resource objectives. Results indicate that the resource objective identified in the AMP for vegetative resources has been met. The objective for livestock forage production has not been met; however, the evaluation found that the grazing system outlined in the AMP has not been followed closely. The vegetation is in good condition and trend is up. The assessment of Standards for Rangeland Health found that the standards for upland watershed function, ecological processes, and Special Status species have been met. The riparian watershed function and water quality issues are not present. The evaluation recommends revising the AMP, following the grazing system more closely, and reducing stocking rate to balance with carrying capacity.

An allotment management evaluation was conducted to analyze, interpret, and evaluate whether or not present management is meeting resource objectives. Results indicate that three of the resource objectives identified in the AMP have not been met and one has been. Trend was found to be static or down. The main factor in not meeting the resource objectives is the result of a trial stocking rate increase during the evaluation period. The assessment of Standards for Rangeland Health found that the standards for upland watershed function, ecological processes, and Special Status species were met. The riparian watershed function and water quality issues are not present. The evaluation recommends reducing the stocking rate to active use to balance with carrying capacity and revising the AMP to formalize a grazing system.

An allotment management evaluation was conducted to analyze, interpret, and evaluate whether or not present management is meeting resource objectives. Results indicate that the resource objectives identified in the AMP have been 
Allotment Allotment

Number Name Categor: Implementation Progress

\section{$* I$ = Improve; $\mathbf{M}=$ Maintain $; \mathbf{C}=$ Custodial}

met. The grazing system has been followed and no revision of the AMP is necessary. The assessment of Standards for Rangeland Health found that the standards for upland watershed function, ecological processes, and Special Status species were met. The riparian watershed function and water quality issues are not present. The stocking rate is well below carrying capacity.

5604 Burnt Flat I

7003 East Wagontire I

7009 Dry Lake I

7014 Badger Springs M

7015 Second Flat I

7016 Juniper Ridge M
An allotment management evaluation was conducted to analyze, interpret, and evaluate whether or not present management is meeting resource objectives. Results indicate that the resource objectives identified in the AMP have been met. The assessment of Standards for Rangeland Health found that the standards for upland watershed function, ecological processes, and Special Status species were met. The riparian watershed function and water quality issues are not present. The evaluation recommends no changes in management at this time.

An allotment management evaluation was conducted to analyze, interpret, and evaluate whether or not present management is meeting resource objectives. Results indicate that the resource objectives identified in the AMP have been met. The assessment of Standards for Rangeland Health found that the standards for upland watershed function, ecological processes, water quality, and Special Status species were met. The riparian watershed function and water quality issues are not present. The evaluation recommends revising the AMP to incorporate a grazing system to address playa management.

Three hundred twenty-four acres of juniper were cut in this allotment to release brush, grass, and forbs.

An allotment management evaluation was conducted to analyze, interpret, and evaluate whether or not present management is meeting resource objectives. Results indicate that the resource objectives identified in the AMP have been met. The assessment of Standards for Rangeland Health found that the standards for upland watershed function, ecological processes, and Special Status species were met. The riparian watershed function and water quality issues are not present. The evaluation recommends no changes in management at this time.

An allotment management evaluation was conducted to analyze, interpret, and evaluate whether or not present management is meeting resource objectives. Results indicate that the resource objectives identified in the AMP have been met. The assessment of Standards for Rangeland Health found that the standards for upland watershed function, ecological processes, and Special Status species were met. The riparian watershed function and water quality issues are not present. The evaluation recommends no changes in management at this time.

An allotment management evaluation was conducted to analyze, interpret, and evaluate whether or not present management is meeting resource objectives. Results indicate that the resource objectives identified in the AMP have been met. The assessment of Standards for Rangeland Health found that the standards for upland watershed function, ecological processes, and Special Status species were met. The riparian watershed function and water quality issues are not present. The evaluation recommends no changes to the grazing system at this time and changing the selective management category to ' $\mathrm{M}$.' 
*I = Improve; $\mathbf{M}=$ Maintain; $\mathbf{C}=$ Custodial

7018 Silver Lake M An allotment management evaluation was conducted to analyze, interpret, and evaluate whether or not present management is meeting resource objectives. Results indicate that the resource objectives identified in the AMP have been met. The assessment of Standards for Rangeland Health found that the standards for upland watershed function, ecological processes, and Special Status species were met. The riparian watershed function and water quality issues are not present. The evaluation recommended changing the selective management category to ' $\mathrm{M}$ ' and revising the grazing system in the AMP. An AMP was developed to incorporate the recommendation from the allotment management evaluation and address conflicts and concerns identified in the Three Rivers RMP. The conflicts and concerns include wetland habitat, Special Status species, playa habitat, and range condition. The objectives are to:

-maintain all seral stages in current status to provide a diversity of habitat types, conditions and forage requirements in all of the pastures during the next four grazing cycles,

-maintain the availability and production of upland forbs for sage grouse from May to mid-July during the next 10 years, while preventing significant risk to the western snowy plover during its nesting period between May 1 to July 31 , each year around Silver Lake.

A grazing system has been developed which will meet these objectives. Key forage species and utilization levels have been identified for each pasture.

7021 Weaver Lake I

7025 Gouldin

7030 Skull Creek

7036 Hayes
An allotment management evaluation was conducted to analyze, interpret, and evaluate whether or not present management is meeting resource objectives. Results indicate that the resource objectives identified in the AMP have been met. The assessment of Standards for Rangeland Health found that the standards for upland watershed function, ecological processes, and Special Status species were met. The riparian watershed function and water quality issues are not present.

An allotment management evaluation was conducted to analyze, interpret, and evaluate whether or not present management is meeting resource objectives. Results indicate that the resource objectives identified in the AMP have been met. The assessment of Standards for Rangeland Health found that the standard for upland watershed function is not being met due to erosion caused by Off-Highway vehicle use in the allotment. The standards for ecological processes and Special Status species are being met. The riparian watershed function and water quality issues are not present. The evaluation recommends modifying the grazing system to allow for growing season rest at least 1 -year out of 3 .

Junipers were cut in two areas in the allotment to reduce competition with big sagebrush, bitterbrush, and ponderosa pine. The units were approximately 250 and 330 acres.

A spring was reconstructed in this allotment to improve the water source for livestock. 
Allotment Allotment

Number Name Category* Implementation Progress

* I = Improve; $\mathrm{M}=$ Maintain; $\mathrm{C}=$ Custodial

7058 Narrows

An allotment management evaluation was conducted to analyze, interpret, and evaluate whether or not present management is meeting resource objectives. Results indicate that the resource objectives identified in the AMP have been met. The assessment of Standards for Rangeland Health found that the standards for upland watershed function, ecological processes, and Special Status species were met. The riparian watershed function and water quality issues are not present. The evaluation recommended revising the grazing system in the AMP. An AMP was developed to incorporate the recommendation from the allotment management evaluation and address conflicts and concerns identified in the Three Rivers RMP. The conflicts and concerns include range condition and Special Status species (sage grouse, long-billed curlew, Malheur wirelettuce). The objective is to:

-maintain the good condition seedings in the Middle and South Pastures. Continue the upward trend in the native plant communities in the North Pasture.

A grazing system has been developed which will meet these objectives. Key forage species and utilization levels have been identified for each pasture.

7063 Round Top I Butte

An allotment management evaluation was conducted to analyze, interpret, and evaluate whether or not present management is meeting resource objectives. Results indicate that the resource objectives identified in the AMP have been met. The assessment of Standards for Rangeland Health found that the standards for upland watershed function, ecological processes, were met and the standard for Special Status species was not met, but the determination is that livestock are not a significant factor. The riparian watershed function and water quality issues are not present. The evaluation recommended revising the grazing system in the AMP. 
Allotments with permits expiring in 2005 are:

No permits expire this year.

Allotments with permits expiring in 2006 are:

\#6002 - South Steens

\#6125 - Roaring Springs FFR 


\title{
FY00 and 01 Accomplishments
}

\author{
Allotment Allotment \\ Number Name Category* Implementation Progress
}

*I = Improve; $\mathbf{M}=$ Maintain; $\mathbf{C}=$ Custodial

6001 North Catlow I On July 12, 2000, 805 acres of public land burned in the Rock Creek Pasture of North Catlow Allotment. The rehabilitation of this fire was analyzed in EA OR-026-00-35. This resulted in reseeding 805 acres with plant species best adapted to that specific site. The area will have a minimum of two growing seasons rest from livestock grazing.

6002 South Steens

The actions outlined in the AMP/EA to accomplish resource objectives continue to be implemented, as well as the continuing implementation of the Catlow Redband Trout and Tui Chub Conservation Agreement and Strategy. The upper elevation pastures, private and public (V-Lake, and Telephone Field) continue to be rested from livestock grazing to prepare for prescribed burns. These pastures, as well as the Blitzen and Penland Pastures, were rested from grazing again in 2000. In 2001, the Penland Pasture will be grazed after seed ripe. Those portions of Blitzen Pasture which do not have access to the public land within the Donner und Blitzen Wild and Scenic River corridor will also be grazed. The Act designated all of the Blitzen Pasture and most of the Penland Pasture as wilderness. Livestock grazing will be phased out of this area within 3 years of completion of the land exchange authorized by the law. The 10-year grazing permit AUM changes and the allotment boundary adjustments will be implemented at this time. The Lauserica fence and Stephens extension fence were completed during the summer of 2000, following the withdrawal of the appeal to the Interior Board of Land Appeals (IBLA) by Oregon Natural Desert Association (ONDA). No prescribed burns were completed during 2000, but were rescheduled for 2001.

On July 12, 2000, 4,817 acres of public land and 3,940 acres of private land burned in the South Catlow Pasture of South Steens Allotment. The possibilities of rehabilitation of this fire were analyzed in EA OR-026-00-35. This resulted in reseeding 8,757 acres of public and private lands in cooperation with Roaring Springs Ranch, with plant species best adapted to that site. The area will have a minimum of two growing seasons rest from livestock grazing.

6003 Fish Creek- I Big Indian

6008 Krumbo
The evaluation and analysis of rangeland monitoring and determination of conformance with the Standards for Rangeland Health is currently being conducted. The 10-year grazing permit expired for this allotment on February 28,2000 . The 10-year grazing permit on this allotment will be reissued under Section 123 of Public Law 106-113. The court order from ONDA v. Green Civil No. 95-2013 HA, which closed public land within the Donner und Blitzen Wild and Scenic River corridor to grazing until the impacts of grazing are analyzed in an EIS, continues to be in effect. As a result Newton Cabin Pasture and Blitzen Meadows have not been grazed since 1996 and continue to be closed to livestock grazing. The Act designated the area within this allotment as wilderness. Livestock grazing will be phased out of this allotment 3 years after completion of the land exchange, authorized in this law. The 10-year grazing permit will be cancelled at this time.

The evaluation and analysis of rangeland monitoring and determination of conformance with the Standards for Rangeland Health. The AMP was signed January 10, 2000. 
Allotment Allotment

Number Name Category* Implementation Progress

*I = Improve; $\mathrm{M}=$ Maintain; $\mathrm{C}=$ Custodial

6010 East Ridge I The East Ridge prescribed burns and juniper cuts (EA OR-026-99-19) are continuing in the mid-canyon of Kiger Gorge. During 2000, 141 acres of juniper were cut to prepare the area for reintroduction of fire. Prescribed burns of approximately 1,000 acres of public land on the east side of the midcanyon are scheduled for October 2001. The Act designated the head of Kiger Gorge as wilderness. Livestock will be phased out of this wilderness, 3 years after completion of the land exchange authorized by this law. The 10-year grazing permit, AUM adjustments, and allotment boundary adjustments will be implemented at that time.

6015 Trout Creek I Mountain

6020 Pueblo-Lone I Mountain

6026 Mann Lake I

6028 Miner's Field I Allotment
Management under the current AMP continues to contribute to an upward trend in riparian areas. Completion of Proper Functioning Condition (PFC) Assessment in 1999 found the majority of streams in the allotment to be in PFC. An October 20, 1999, tour with interested publics resulted in favorable comments on the allotment condition and trend. In 2000, 3.2 miles of fence were realigned on the headwaters of East Fork of Big Trout Creek. This project will serve to further enhance riparian conditions in the East Fork and Headwaters Pastures. An EA was completed in June 2000, which analyzes the impacts of construction of a 2-mile division fence in the Upper Antelope Pasture. This fence is intended to improve early season use in this seeding, thereby further reducing grazing pressure on higher elevation native pastures. Both projects have been completed.

During the winter of FY00, 1,000 acres in the Colony Seeding Pasture were disced and reseeded to a mixture of crested wheatgrass, forage kochia, Great Basin wildrye, and fourwing saltbush. The pasture will be rested from grazing for two growing seasons following this seeding rehabilitation effort. A fence was constructed to exclude Tum Tum Lake from livestock grazing. Both projects were also identified in the AMP.

An assessment of the Rincon pipeline was completed in 2000 , to determine possibilities for increased water efficiencies. This pipeline was built in the early 1960's, and while functioning well, is due for maintenance and upgrading. The purpose of this effort is to improve overland water flow at Dip Spring, which supplies water to the pipeline. The pipeline was replaced as needed, and new troughs and storage tank installed.

Grazing use according to the Pueblo-Lone Mountain AMP continues to result in improved upland meadow and riparian conditions. Continued protection of Van Horn Creek from livestock use is contributing to improved riparian and aquatic conditions for the resident Lahontan cutthroat trout.

The evaluation and analysis of rangeland monitoring and determination of conformance with the Standards for Rangeland Health is currently being conducted.

On August 3, 2000, a lightning-caused wildfire occurred (Alvord Peaks Fire) in the Bone Creek Field of Miner's Field Allotment, approximately 60 acres were reseeded with native species. The Bone Creek Field was rested from livestock grazing during 2000 and 2001. The Act, Section 113(3)(A)(B)(C) outlines the reallocation of available forage in the Miner's Field Allotment. 
Allotment Allotment

Number Name Category* Implementation Progress

\section{*I = Improve; $\mathrm{M}=$ Maintain; $\mathrm{C}=$ Custodial}

6034 West Slope M A 3.8-mile allotment boundary fence is scheduled to be constructed in the summer of 2001 to improve riparian management on about 12 miles of McCoy Creek and its tributaries.

6040 Stonehouse

The analysis and evaluation of monitoring studies were completed by the BLM during 1999. This evaluation determined that the current livestock management on this allotment was not in conformance with the Standards for Rangeland Health. The issues addressed in the evaluation, and subsequently in the EA/AMP, are riparian condition of upper Riddle Creek, Stonehouse Creek, fisheries, WSAs, upland range condition, sage grouse habitat, condition of wetland meadows, juniper encroachment, and the reintroduction of fire. The EA/AMP (EA OR-026-99-47) which resulted from this evaluation was circulated for public review during May of 2000. The EA was revised to analyze the prescribed burns and was available for public review during March 2001. The Finding of No Significant Impact (FONSI)/final decision was appealed to the IBLA and a "Stay of the Decision" requested. The issued appeal was the prescribed burning of 3,600 acres and 3 years of rest from livestock. Due to public comments received on this EA/AMP and the Act, the AMP will be coordinated with the SMAC and interested publics and reissued for public review in 2002 or 2003. 


\section{ENVIRONMENTAL ASSESSMENT REGISTER}

\section{The following are Environmental Assessments (EAs) which were scheduled but were not completed and new EAs recently initiated. The EAs for these projects are expected to be completed in FY02. A notice is published in the Burns Times-Herald when each new EA is available for review by the public and the date when the comment period ends.}

Additional EAs, not currently scheduled, may be initiated throughout the year. Examples of these are EAs for Special Recreation Permits, motorized access into the Steens Wilderness Area, etc. If you would like copies of these or other unscheduled EAs, let us know.

If you would like to be involved in the planning process for any particular project or would simply like to receive a copy of an EA for review, note the EA register number and contact the District or the project's primary contact listed below. This should be done as early as possible to allow for full consideration of your input.

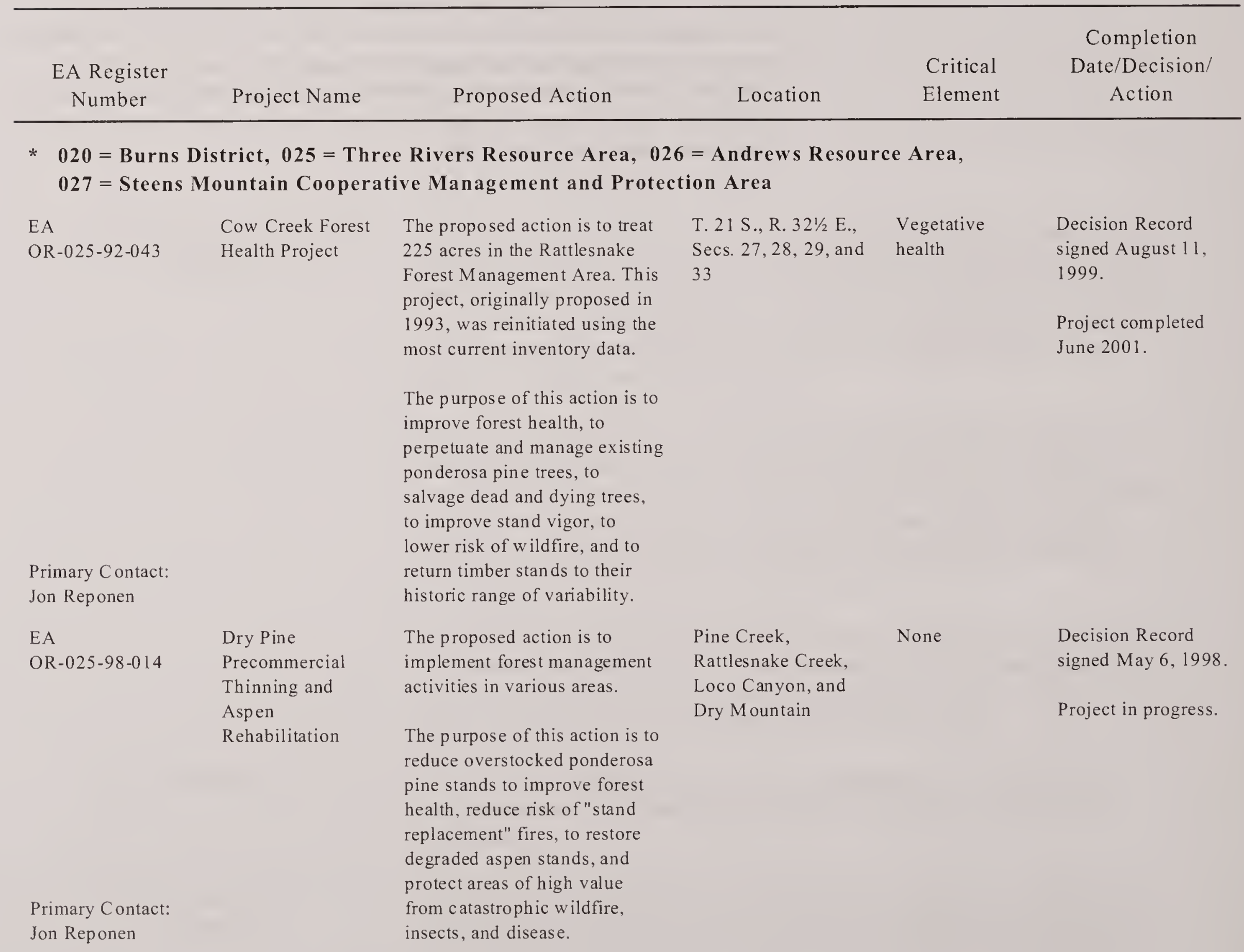




\begin{tabular}{|c|c|c|c|c|c|}
\hline $\begin{array}{l}\text { EA Register } \\
\text { Number }\end{array}$ & Project Name & Proposed Action & Location & $\begin{array}{l}\text { Critical } \\
\text { Element }\end{array}$ & $\begin{array}{c}\text { Completion } \\
\text { Date/Decision/ } \\
\text { Action }\end{array}$ \\
\hline $\begin{array}{l}\text { EA } \\
\text { OR-025-99-011 }\end{array}$ & Exclosure Fences & $\begin{array}{l}\text { The proposed action is to } \\
\text { construct exclosure fences } \\
\text { around unalloted areas having } \\
\text { Special Status plant } \\
\text { populations in order to exclude } \\
\text { livestock from these areas. }\end{array}$ & $\begin{array}{l}\text { Various locations in } \\
\text { Three Rivers RA }\end{array}$ & $\begin{array}{l}\text { Special Status } \\
\text { plants }\end{array}$ & $\begin{array}{l}\text { Decision Record } \\
\text { was signed } \\
\text { April } 11,2000 . \\
\text { Project will be } \\
\text { completed when } \\
\text { funding is available. }\end{array}$ \\
\hline $\begin{array}{l}\text { Primary Contact: } \\
\text { Nora Taylor }\end{array}$ & & $\begin{array}{l}\text { The purpose of this action is to } \\
\text { protect Special Status plant } \\
\text { populations. }\end{array}$ & & & \\
\hline $\begin{array}{l}\text { EA } \\
\text { OR-025-99-014 }\end{array}$ & $\begin{array}{l}\text { Newell Forest } \\
\text { Health Project }\end{array}$ & $\begin{array}{l}\text { The proposed action is to } \\
\text { reduce road density, } \\
\text { reconstruct road segments } \\
\text { causing sedimentation in to } \\
\text { creeks, rehabilitate riparian } \\
\text { areas, improve aspen and } \\
\text { mountain mahogany stands, } \\
\text { reduce hazardous fuel } \\
\text { loadings, improve forest health } \\
\text { through stocking control by } \\
\text { using precommercial thinning } \\
\text { and harvesting of commercial } \\
\text { size material. }\end{array}$ & $\begin{array}{l}\text { East side of Silvies } \\
\text { Valley }\end{array}$ & Riparian & $\begin{array}{l}\text { EA complete } \\
\text { February } 2000 . \\
\text { Decision Record is } \\
\text { pend ing. }\end{array}$ \\
\hline $\begin{array}{l}\text { Primary Contact: } \\
\text { Jon Reponen }\end{array}$ & & $\begin{array}{l}\text { The purpose of this action is to } \\
\text { improve water quality, to } \\
\text { reduce the risk of wildfire, to } \\
\text { improve wildlife habitat, and } \\
\text { to improve the health and vigor } \\
\text { of the area's timber stands. }\end{array}$ & & & \\
\hline $\begin{array}{l}\text { EA } \\
\text { OR-025-99-016 }\end{array}$ & $\begin{array}{l}\text { Clear Creek } \\
\text { Riparian Pasture } \\
\text { Fence }\end{array}$ & $\begin{array}{l}\text { The proposed action is to } \\
\text { construct } 6 \text { miles of fence. }\end{array}$ & $\begin{array}{l}\text { T. } 22 \text { S., R. } 34 \text { E., } \\
\text { Stinkingwater } \\
\text { Allotment }\end{array}$ & $\begin{array}{l}\text { Biscuitroot } \\
\text { Cultural ACEC }\end{array}$ & $\begin{array}{l}\text { Project to be } \\
\text { completed when } \\
\text { funding is available. }\end{array}$ \\
\hline $\begin{array}{l}\text { Primary Contact: } \\
\text { Jim King }\end{array}$ & & $\begin{array}{l}\text { The purpose of this action is to } \\
\text { create a separate pasture to } \\
\text { protect and enhance riparian } \\
\text { areas. }\end{array}$ & & & \\
\hline $\begin{array}{l}\text { EA } \\
\text { OR-025-99-017 }\end{array}$ & $\begin{array}{l}\text { Stinkingwater } \\
\text { Allotment W ater } \\
\text { Development }\end{array}$ & $\begin{array}{l}\text { The proposed action is to } \\
\text { develop three springs and one } \\
\text { waterhole. }\end{array}$ & $\begin{array}{l}\text { Stinkingw ater } \\
\text { Allotment }\end{array}$ & $\begin{array}{l}\text { Biscuitroot } \\
\text { Cultural ACEC }\end{array}$ & $\begin{array}{l}\text { EA complete, } \\
\text { Decision Record is } \\
\text { pending. }\end{array}$ \\
\hline $\begin{array}{l}\text { Primary Contact: } \\
\text { Jim King }\end{array}$ & & $\begin{array}{l}\text { The purpose of this action is to } \\
\text { achieve better livestock } \\
\text { distribution. }\end{array}$ & & & \\
\hline $\begin{array}{l}\text { EA } \\
\text { OR-025-99-045 }\end{array}$ & $\begin{array}{l}\text { Weed Lake Butte } \\
\text { Fire } \\
\text { Rehabilitation }\end{array}$ & $\begin{array}{l}\text { The proposed action is to apply } \\
\text { seed and construct fence. }\end{array}$ & $\begin{array}{l}\text { T. } 27 \text { S.; R. } 29 \text { E., } \\
\text { Secs. } 23,24, \text { and } 36\end{array}$ & None & $\begin{array}{l}\text { Project com plete } \\
\text { April } 2001\end{array}$ \\
\hline $\begin{array}{l}\text { Primary Contact: } \\
\text { Jim King }\end{array}$ & & $\begin{array}{l}\text { The purpose of this action is to } \\
\text { rehabilitate an area burned by } \\
\text { wild fire. }\end{array}$ & & & \\
\hline $\begin{array}{l}\text { EA } \\
\text { OR-025-99-048 }\end{array}$ & $\begin{array}{l}\text { Windy Point-Jack } \\
\text { Mountain Fire } \\
\text { Rehabilitation }\end{array}$ & $\begin{array}{l}\text { The proposed action is to apply } \\
\text { seed and construct fence. } \\
\text { The purpose of this action is to } \\
\text { rehabilitate an area burned by } \\
\text { wild fire. }\end{array}$ & $\begin{array}{l}\text { Princeton, Jack } \\
\text { Mountain } \\
\text { T. } 28 \text { S.; R. } 30 \text { E.; } \\
\text { Secs. } 27,28 \text {, and } 33\end{array}$ & None & $\begin{array}{l}\text { EA completed. } \\
\text { Decision Record } \\
\text { signed } \\
\text { September } 20 \text {, } \\
1999 .\end{array}$ \\
\hline $\begin{array}{l}\text { Primary Contact: } \\
\text { Nora Taylor }\end{array}$ & & & & & $\begin{array}{l}\text { Project com pleted } \\
\text { November } 2000 .\end{array}$ \\
\hline
\end{tabular}




\begin{tabular}{|c|c|c|c|c|c|}
\hline $\begin{array}{l}\text { EA Register } \\
\text { Number }\end{array}$ & Project Name & Proposed Action & Location & $\begin{array}{l}\text { Critical } \\
\text { Element }\end{array}$ & $\begin{array}{l}\text { Completion } \\
\text { Date/Decision/ } \\
\text { Action }\end{array}$ \\
\hline $\begin{array}{l}\text { EA } \\
\text { OR-025-99-50 }\end{array}$ & $\begin{array}{l}\text { Otis Mountain } \\
\text { Ecosystem } \\
\text { Restoration } \\
\text { Project }\end{array}$ & $\begin{array}{l}\text { The proposed action is to use } \\
\text { prescribed fire and mechanical } \\
\text { methods to reduce juniper } \\
\text { encroachment. } \\
\text { The purpose of this action is to } \\
\text { restore sage grouse habitat and } \\
\text { to improve and rehabilitate } \\
\text { aspen and mountain mahogany } \\
\text { stands. }\end{array}$ & $\begin{array}{l}\text { Otis Mountain Area; } \\
\text { T. } 18 \mathrm{~S} . ; \text { R. } 35 \mathrm{E} . \text {, } \\
\text { Secs. 26, 27, 28, 29, } \\
30,31,32,33,34 \text {, } \\
\text { and } 35\end{array}$ & None & $\begin{array}{l}\text { Decision Record } \\
\text { signed June } 2000 \text {. } \\
\text { *Long-term project } \\
\text { ( } 15 \text { years) (two of } \\
\text { the five units have } \\
\text { been treated, one } \\
\text { juniper cutting and } \\
\text { one prescribed fire) }\end{array}$ \\
\hline $\begin{array}{l}\text { Primary Contact: } \\
\text { Rudy Hefter }\end{array}$ & $\begin{array}{l}\text { Three Rivers } \\
\text { Juniper } \\
\text { Management } \\
\text { Project }\end{array}$ & $\begin{array}{l}\text { The proposed action is to use } \\
\text { mechanical means to cut } \\
\text { juniper. } \\
\text { The purpose of this action is to } \\
\text { improve and restore sage } \\
\text { grouse habitat, to improve and } \\
\text { restore aspen and mountain } \\
\text { mahogany stands, and to } \\
\text { improve riparian areas. }\end{array}$ & $\begin{array}{l}\text { North of Hwy } 20 \\
\text { and in the } \\
\text { Stinkingwater and } \\
\text { Riddle Mountain } \\
\text { Areas }\end{array}$ & $\begin{array}{l}A C E C, \\
\text { riparian }\end{array}$ & $\begin{array}{l}\text { EA completed. } \\
\text { Decision Record } \\
\text { signed April 17, } \\
2000 . \\
\text { This is a } \\
\text { programmatic EA } \\
\text { with a series of } \\
\text { projects. }\end{array}$ \\
\hline $\begin{array}{l}\text { EA } \\
\text { OR-025-00-11 }\end{array}$ & $\begin{array}{l}\text { Mountains } \\
\text { Grazing Use } \\
\text { Project }\end{array}$ & $\begin{array}{l}\text { The proposed action is to } \\
\text { change season of use for } \\
\text { grazing in the Mountain and } \\
\text { Upton Mountain Allotments. }\end{array}$ & $\begin{array}{l}\text { T. } 23 \text { S.; R. } 35 \text { E., } \\
\text { Sec. } 18\end{array}$ & Riparian & EA was dropped. \\
\hline $\begin{array}{l}\text { Primary Contact: } \\
\text { Bill Andersen }\end{array}$ & & $\begin{array}{l}\text { The purpose of this action is to } \\
\text { improve upland range } \\
\text { conditions. }\end{array}$ & & & \\
\hline $\begin{array}{l}\text { Primary Contact: } \\
\text { Rudy Hefter }\end{array}$ & $\begin{array}{l}\text { Maintaining } \\
\text { Viable } \\
\text { Populations of } \\
\text { Wild Horses in } \\
\text { the Stinkingwater } \\
\text { HMA }\end{array}$ & $\begin{array}{l}\text { The proposed action is to } \\
\text { gather wild horses. } \\
\text { The purpose of this action is to } \\
\text { meet Appropriate Management } \\
\text { Levels (AMLs). }\end{array}$ & $\begin{array}{l}\text { Stinkingwater Herd } \\
\text { Management Area }\end{array}$ & $\mathrm{ACEC}$ & $\begin{array}{l}\text { EA Decision } \\
\text { Record was signed } \\
\text { on July } 26,2000 . \\
\text { Horses to be } \\
\text { gathered FY02. }\end{array}$ \\
\hline $\begin{array}{l}\text { EA } \\
\text { OR-025-00-18 }\end{array}$ & $\begin{array}{l}\text { Devils Slide } \\
\text { Fence }\end{array}$ & $\begin{array}{l}\text { The proposed action is to } \\
\text { construct } 0.3 \text {-mile of fence. }\end{array}$ & $\begin{array}{l}\text { T. } 18 \text { S.; R. } 33 \frac{112}{} \text { E.; } \\
\text { Sec. } 26\end{array}$ & None & $\begin{array}{l}\text { EA Decision } \\
\text { Record signed } \\
\text { July } 12,2000 .\end{array}$ \\
\hline $\begin{array}{l}\text { Primary Contact: } \\
\text { Leslie Richman }\end{array}$ & & $\begin{array}{l}\text { The purpose of this action is to } \\
\text { implement rest rotation and } \\
\text { improve cattle distribution. }\end{array}$ & & & $\begin{array}{l}\text { Project not funded } \\
\text { yet. }\end{array}$ \\
\hline $\begin{array}{l}\text { EA } \\
\text { OR-020-00-19 }\end{array}$ & $\begin{array}{l}\text { Programmatic EA } \\
\text { for Commercial } \\
\text { Outfitting }\end{array}$ & $\begin{array}{l}\text { The proposed action is to } \\
\text { establish direction and } \\
\text { guidance for issuing outfitter } \\
\text { guide permits for other than } \\
\text { day-use permits. }\end{array}$ & Districtwide & $\begin{array}{l}\text { WSAs, Wild } \\
\text { and Scenic } \\
\text { Rivers (WSRs), } \\
\text { ACECs, etc. }\end{array}$ & $\mathrm{EA}$ is pending. \\
\hline $\begin{array}{l}\text { Primary Contact: } \\
\text { Fred McDonald }\end{array}$ & & $\begin{array}{l}\text { The purpose of this action is to } \\
\text { establish criteria and identify a } \\
\text { process for issuing commercial } \\
\text { outfitter/guide permits. }\end{array}$ & & & \\
\hline $\begin{array}{l}\text { Primary Contact: } \\
\text { Rudy Hefter }\end{array}$ & $\begin{array}{l}\text { Maintaining } \\
\text { Viable } \\
\text { Populations of } \\
\text { Wild Horses in } \\
\text { the Warm Springs } \\
\text { Herd } \\
\text { Management Area }\end{array}$ & $\begin{array}{l}\text { The proposed action is to } \\
\text { gather wild horses. } \\
\text { The purpose of this action is to } \\
\text { meet AMLs. }\end{array}$ & Warm Springs HM A & None & $\begin{array}{l}\text { EA Decision } \\
\text { Record signed } \\
\text { August } 24,2000 . \\
\text { Gather completed } \\
\text { FY01. }\end{array}$ \\
\hline
\end{tabular}




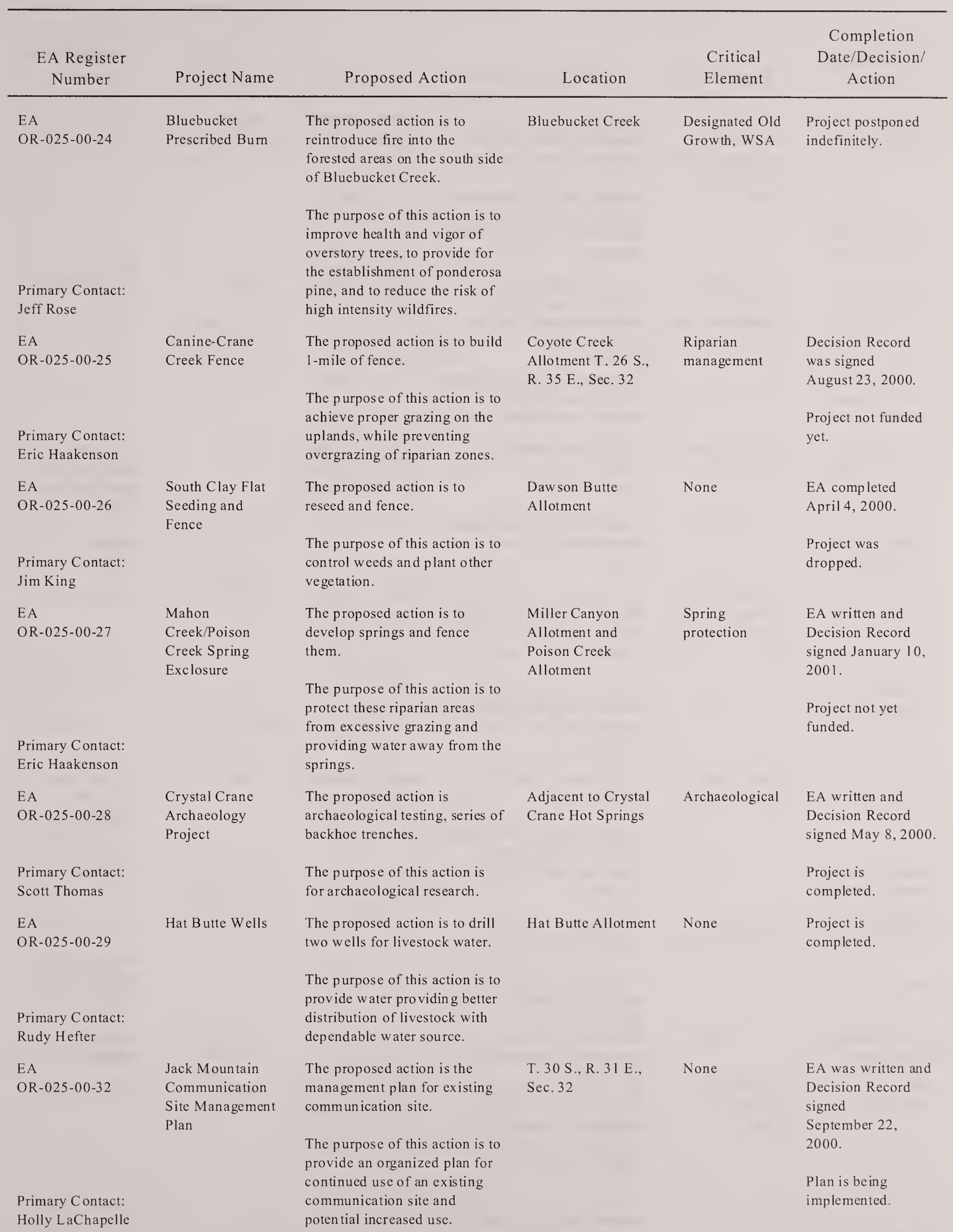




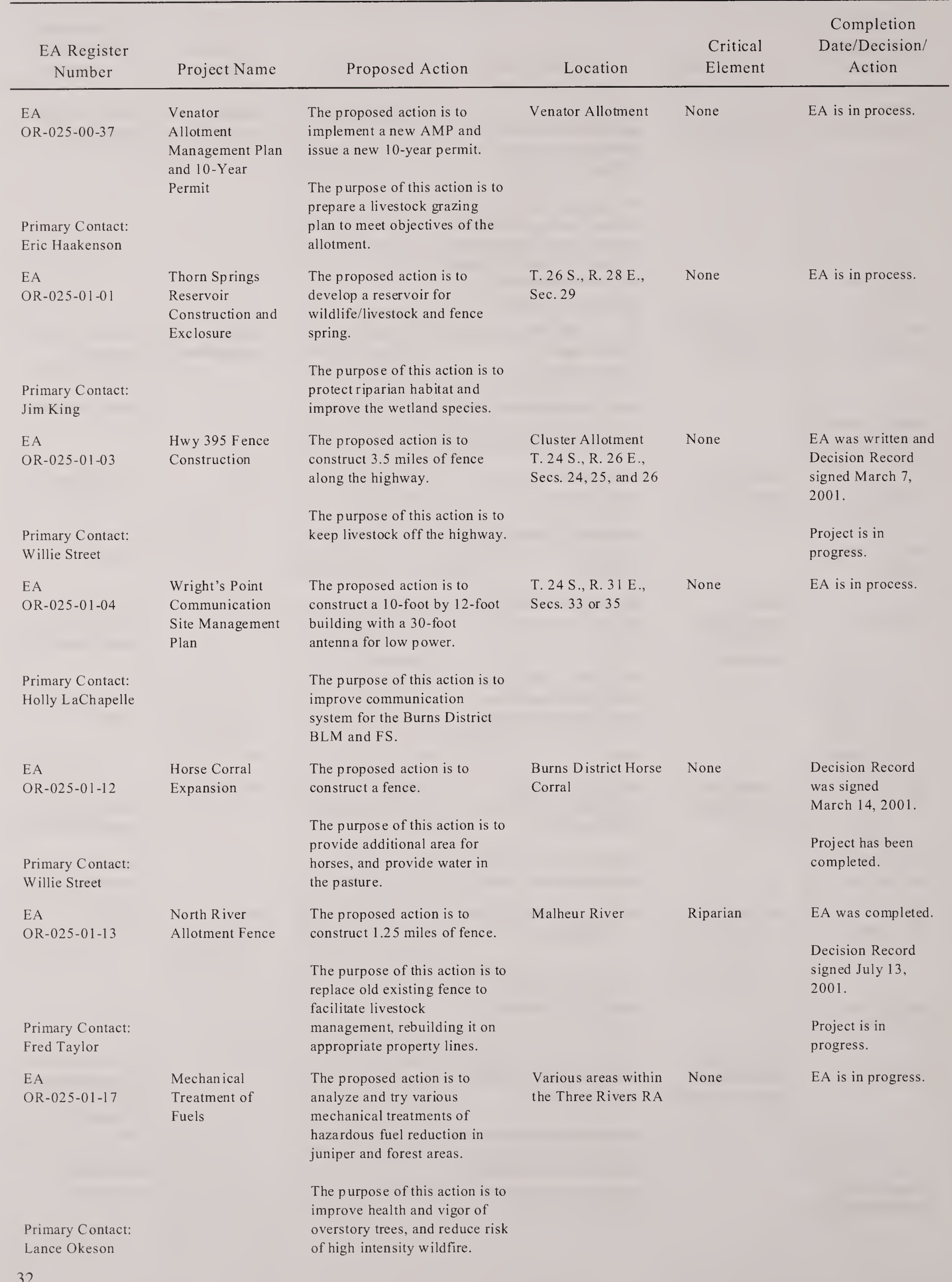




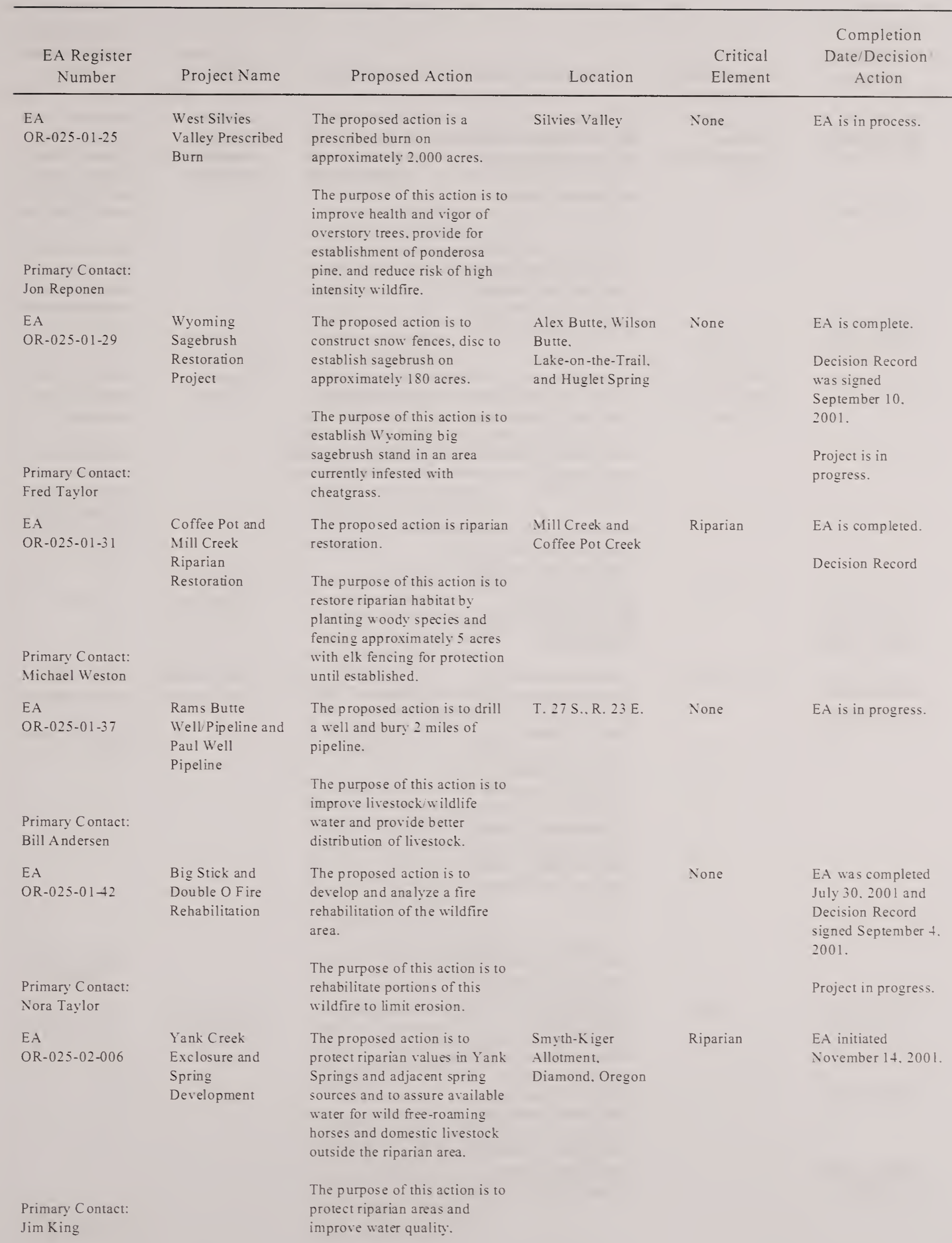




\begin{tabular}{|c|c|c|c|c|c|}
\hline $\begin{array}{l}\text { EA Register } \\
\text { Number }\end{array}$ & Project Name & Proposed Action & Location & $\begin{array}{l}\text { Critical } \\
\text { Element }\end{array}$ & $\begin{array}{c}\text { Completion } \\
\text { Date/Decision/ } \\
\text { Action }\end{array}$ \\
\hline $\begin{array}{l}\text { EA } \\
\text { OR-026-94-059 }\end{array}$ & $\begin{array}{l}\text { Stonehouse } \\
\text { Allotment } \\
\text { Management Plan } \\
\text { (AMP) }\end{array}$ & $\begin{array}{l}\text { The proposed action is to } \\
\text { implement a grazing system } \\
\text { and prescribed fire on the } \\
\text { Stonehouse Allotment. This } \\
\text { will be based on the } \\
\text { evaluation. }\end{array}$ & $\begin{array}{l}\text { T. } 30 \text { and } 31 \mathrm{~S} . \text {, } \\
\text { R. } 34 \text { and } 35 \mathrm{E} . \\
\text { northeast side of } \\
\text { Steens Mountain }\end{array}$ & $\begin{array}{l}\text { WSA; Riddle } \\
\text { Creek and } \\
\text { headwaters of } \\
\text { Deep Creek }\end{array}$ & $\begin{array}{l}\text { Allotment } \\
\text { evaluation was } \\
\text { completed May } \\
2000, \text { revised and } \\
\text { sent for public } \\
\text { review March } 2001 .\end{array}$ \\
\hline $\begin{array}{l}\text { Primary Contact: } \\
\text { Jim Buchanan }\end{array}$ & & $\begin{array}{l}\text { The purpose of this action is to } \\
\text { improve riparian and upland } \\
\text { range condition and plant } \\
\text { diversity on sagebrush and } \\
\text { juniper-dominated sites. }\end{array}$ & 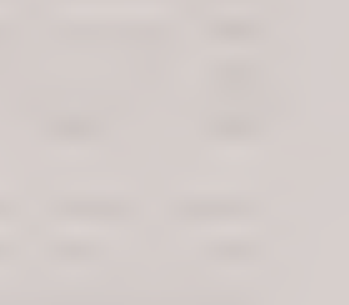 & & $\begin{array}{l}\text { The Decision was } \\
\text { revised to only } \\
\text { include the } \\
\text { prescribed fire and } \\
\text { was appealed to } \\
\text { IBLA. }\end{array}$ \\
\hline $\begin{array}{l}\text { Primary Contact: } \\
\text { Mark Sherboume }\end{array}$ & $\begin{array}{l}\text { Davis/ } \\
\text { Wildhorse Land } \\
\text { Exchange }\end{array}$ & $\begin{array}{l}\text { The proposed action is to } \\
\text { exchange approximately } \\
\text { 1,945 acres of public land for } \\
3,992 \text { acres of private land } \\
\text { around Mickey and Tule } \\
\text { Springs and Stonehouse and } \\
\text { Carlson Creeks. } \\
\text { The purpose of this action is to } \\
\text { consolidate public and private } \\
\text { lands into more manageable } \\
\text { units and acquire important } \\
\text { wildlife, riparian, and } \\
\text { recreation values and important } \\
\text { public access. }\end{array}$ & $\begin{array}{l}\text { Stonehouse and } \\
\text { Carlson Creeks; } \\
\text { Mickey and Tule } \\
\text { Springs; east slopes } \\
\text { of Steens Mountain } \\
\text { and Alvord Desert }\end{array}$ & $\begin{array}{l}\text { Riparian, } \\
\text { recreation }\end{array}$ & $\begin{array}{l}\text { EA scheduled for } \\
\text { FY00, was not } \\
\text { completed. } \\
\text { This action was } \\
\text { included in the } \\
\text { Steens Mountain } \\
\text { legislation and this } \\
\text { EA is dropped. }\end{array}$ \\
\hline $\begin{array}{l}\text { EA } \\
\text { OR-026-98-033 }\end{array}$ & Lauserica Fence & $\begin{array}{l}\text { The proposed action is to } \\
\text { construct approximately } \\
9.1 \text { miles of fence ( } 7.7 \text { miles on } \\
\text { public, } 1.4 \text { miles on private } \\
\text { land) to separate the Steens } \\
\text { Pasture from the Home Creek } \\
\text { Pasture and to construct } \\
\text { approximately 1-mile of fence } \\
\text { on public land to separate } \\
\text { Home Creek Pasture from } \\
\text { Stephens Pasture. Existing } \\
\text { nonfunctional fence would be } \\
\text { removed. }\end{array}$ & $\begin{array}{l}\text { T. } 34 \text { S., R. } 31 \text { and } \\
32 \text { E. }\end{array}$ & $\begin{array}{l}\text { WS As, Special } \\
\text { Status species }\end{array}$ & $\begin{array}{l}\text { Appeal to IBLA } \\
\text { was withdrawn and } \\
\text { project was } \\
\text { completed August } \\
2000 .\end{array}$ \\
\hline & & $\begin{array}{l}\text { The purpose of the proposed } \\
\text { activity is to provide additional } \\
\text { livestock control enabling } \\
\text { more effective management of } \\
\text { livestock grazing. This will } \\
\text { facilitate activities necessary to } \\
\text { achieve the conservation goals } \\
\text { of the Conservation } \\
\text { Agreement, rangeland } \\
\text { improvement goals of the } \\
\text { Sou th Steens AMP, and water } \\
\text { quality goals of the South }\end{array}$ & & & \\
\hline $\begin{array}{l}\text { Primary Contact: } \\
\text { Jim Buchanan }\end{array}$ & & $\begin{array}{l}\text { Steens Water Quality } \\
\text { Management Plan (WQMP). }\end{array}$ & & & \\
\hline
\end{tabular}




\begin{tabular}{|c|c|c|c|c|c|}
\hline $\begin{array}{l}\text { Primary Contact: } \\
\text { Carolyn Chad }\end{array}$ & $\begin{array}{l}\text { East Fork/ } \\
\text { Headwaters Fence } \\
\text { Realignment }\end{array}$ & $\begin{array}{l}\text { The proposed action is to } \\
\text { remove fence and realign the } \\
\text { pasture division fence in Trout } \\
\text { Creek Allotment. } \\
\text { The purpose is to el iminate the } \\
\text { need for an existing uneffective } \\
\text { exclosure along the east fork of } \\
\text { Trout Creek, and to remove the } \\
\text { existing pasture fence from a } \\
\text { snow field. }\end{array}$ & $\begin{array}{l}\text { T. } 41 \mathrm{~S} ., \text { R. } 38 \text { E., } \\
\text { various sections }\end{array}$ & WSA & $\begin{array}{l}\text { EA and Decision } \\
\text { Record signed } \\
\text { October } 12,1999 . \\
\text { Project will be } \\
\text { completed FY01. }\end{array}$ \\
\hline $\begin{array}{l}\text { Primary Contact: } \\
\text { Mark Sherbourne }\end{array}$ & & $\begin{array}{l}\text { The purpose of this action is to } \\
\text { prevent cattle movement } \\
\text { between the two allotments, } \\
\text { and to improve management } \\
\text { along approximately } 12 \text { miles } \\
\text { of McCoy Creek and its } \\
\text { tributaries. }\end{array}$ & & & \\
\hline $\begin{array}{l}\text { EA } \\
\text { OR-026-99-019 }\end{array}$ & $\begin{array}{l}\text { East Ridge } \\
\text { Prescribed Burns } \\
\text { and Juniper } \\
\text { Cutting }\end{array}$ & $\begin{array}{l}\text { The proposed action is to cut } \\
\text { juniper in preparation to } \\
\text { restore the natural function of } \\
\text { fire within aspen stands and } \\
\text { adjacent to riparian zone } \\
\text { within Kiger Gorge. } \\
\text { Approximately } 2,000 \text { acres of } \\
\text { public land would have fire } \\
\text { reintroduction within a } \\
5-10 \text { year period. }\end{array}$ & $\begin{array}{l}\text { T. } 31 \mathrm{~S} . \text {, } \\
\text { R. } 33 \text { and } 34 \mathrm{E} . \\
\text { Secs. } 3,6,7,11,18 \text {, } \\
19, \text { and } 30\end{array}$ & Kiger Creek & $\begin{array}{l}\text { EA was completed } \\
\text { and Decision } \\
\text { Record signed } \\
\text { August } 25,1999 . \\
\text { Ongoing project. } \\
\text { Cuttings are } \\
\text { complete, burning } \\
\text { planned for fall } \\
2001 \text {. }\end{array}$ \\
\hline $\begin{array}{l}\text { Primary Contact: } \\
\text { Jim Buchanan }\end{array}$ & & $\begin{array}{l}\text { The purpose of this action is to } \\
\text { restore species' diversity to } \\
\text { remnant aspen stands curren tly } \\
\text { dominated by western juniper } \\
\text { and to allow deciduous woody } \\
\text { species to expand in } \\
\text { community dominance along } \\
\text { stream segments where juniper } \\
\text { is filling the niche of these } \\
\text { species. The purpose is also to } \\
\text { restore ecological function. }\end{array}$ & & & \\
\hline $\begin{array}{l}\text { EA } \\
\text { OR-026-00-12 }\end{array}$ & $\begin{array}{l}\text { Upper Antelope } \\
\text { Division Fence }\end{array}$ & $\begin{array}{l}\text { The proposed action is to } \\
\text { construct approximately } \\
2 \text { miles of fence to divide the } \\
\text { Upper Antelope Pasture into } \\
\text { two units. }\end{array}$ & $\begin{array}{l}\text { T. } 40 \text { S., R. } 36 \text { E., } \\
\text { Secs. } 3 \text { and } 4\end{array}$ & None & $\begin{array}{l}\text { Decision Record } \\
\text { signed August } 8 \text {, } \\
2000 . \\
\text { Project completed } \\
\text { March 21, 2001. }\end{array}$ \\
\hline $\begin{array}{l}\text { Primary Contact: } \\
\text { Carolyn Chad }\end{array}$ & & $\begin{array}{l}\text { The purpose of this action is to } \\
\text { adjust grazing patterns in the } \\
\text { crested wheatgrass seeding } \\
\text { within the pasture, and } \\
\text { improve the overall flexibility } \\
\text { of the Trout Creek Mountain } \\
\text { grazing rotation system. }\end{array}$ & & & \\
\hline
\end{tabular}




\begin{tabular}{|c|c|c|c|c|c|}
\hline $\begin{array}{l}\text { EA Register } \\
\text { Number }\end{array}$ & Project Name & Proposed Action & Location & $\begin{array}{l}\text { Critical } \\
\text { Element }\end{array}$ & $\begin{array}{c}\text { Completion } \\
\text { Date/Decision/ } \\
\text { Action }\end{array}$ \\
\hline $\begin{array}{l}\text { EA } \\
\text { OR-026-00-17 }\end{array}$ & Doe Camp Fence & $\begin{array}{l}\text { The proposed action is to } \\
\text { construct } 3.5 \text { miles of riparian } \\
\text { fence. }\end{array}$ & $\begin{array}{l}\text { Lower McCoy } \\
\text { Creek }\end{array}$ & Riparian area & $\begin{array}{l}\text { Decision Record } \\
\text { signed } \\
\text { November } 30,2000 \text {. }\end{array}$ \\
\hline $\begin{array}{l}\text { Primary Contact: } \\
\text { Manny Berain }\end{array}$ & & $\begin{array}{l}\text { The purpose of this action is to } \\
\text { improve riparian conditions on } \\
3.5 \text { miles of McCoy Creek and } \\
\text { l-mile of Horton Creek to help } \\
\text { meet allotment objectives of } \\
\text { maintaining and/or enhancing } \\
\text { water quality and ecological } \\
\text { status of riparian vegetation. }\end{array}$ & & & $\begin{array}{l}\text { Project to be } \\
\text { completed FY01. }\end{array}$ \\
\hline $\begin{array}{l}\text { EA } \\
\text { OR-026-00-31 }\end{array}$ & $\begin{array}{l}\text { Tiller Cabin } \\
\text { Remediation }\end{array}$ & $\begin{array}{l}\text { The proposed action is to } \\
\text { remove cabin and other related } \\
\text { material. }\end{array}$ & $\begin{array}{l}\text { T. } 41 \text { S.. R. } 34 \text { E., } \\
\text { Sec. } 11\end{array}$ & WSA & $\begin{array}{l}\text { EA was written and } \\
\text { Decision signed } \\
\text { August } 10,2000 .\end{array}$ \\
\hline $\begin{array}{l}\text { Primary Contact: } \\
\text { Terri Geisler }\end{array}$ & & $\begin{array}{l}\text { The purpose of this action is to } \\
\text { restore an old mine claim and } \\
\text { for public safety. }\end{array}$ & & & $\begin{array}{l}\text { Project has been } \\
\text { completed. }\end{array}$ \\
\hline $\begin{array}{l}\text { EA } \\
\text { OR-026-00-35 }\end{array}$ & $\begin{array}{l}\text { Beatys Butte Fire } \\
\text { Rehabilitation }\end{array}$ & $\begin{array}{l}\text { The proposed action is to drill } \\
\text { seed on approximately } 15,000 \\
\text { acres and reconstruct } 6 \text { miles } \\
\text { of fence, build } 7 \text { miles of } \\
\text { protection fence. }\end{array}$ & & None & $\begin{array}{l}\text { EA written and } \\
\text { Decision Record } \\
\text { signed } \\
\text { September } 13 \text {, } \\
2000 .\end{array}$ \\
\hline $\begin{array}{l}\text { Primary Contact: } \\
\text { Jim Buchanan }\end{array}$ & & $\begin{array}{l}\text { The purpose of this action is to } \\
\text { close the area to grazing for } 2 \\
\text { years, or as needed, to allow } \\
\text { establishment of perennial } \\
\text { plant species seeded to prevent } \\
\text { cheatgrass invasion. }\end{array}$ & & & $\begin{array}{l}\text { Project is } \\
\text { completed. }\end{array}$ \\
\hline $\begin{array}{l}\text { EA } \\
\text { OR-026-00-38 }\end{array}$ & $\begin{array}{l}\text { Alvord Fire } \\
\text { Rehabilitation }\end{array}$ & $\begin{array}{l}\text { The proposed action is to drill } \\
\text { seed approximately } 170 \text { acres } \\
\text { in burns area and repair road } \\
\text { and erosion barriers. }\end{array}$ & Scoubes Creek & WSA & $\begin{array}{l}\text { EA written with } \\
\text { Decision Record } \\
\text { signed } \\
\text { November } 15,2000 \text {. }\end{array}$ \\
\hline $\begin{array}{l}\text { Primary Contact: } \\
\text { Manny Berain }\end{array}$ & & $\begin{array}{l}\text { The purpose of this action is to } \\
\text { close the area to grazing for } \\
2 \text { years, or as needed, to allow } \\
\text { establishment of seeded } \\
\text { perennial plant species to } \\
\text { prevent cheatgrass invasion } \\
\text { and to place structures on } \\
\text { intermittent stream tributaries } \\
\text { to slow water and capture soil } \\
\text { movement. }\end{array}$ & & & Project is complete. \\
\hline $\begin{array}{l}\text { EA } \\
\text { OR-026-01-08 }\end{array}$ & $\begin{array}{l}\text { North Catlow } \\
\text { Winter Pasture } \\
\text { Fence, Pipeline } \\
\text { and Trough }\end{array}$ & $\begin{array}{l}\text { The proposed action is to } \\
\text { construct two fences } 6 \text { miles } \\
\text { each; install } 4 \text { miles of pipeline } \\
\text { and two } 30 \text {-foot troughs for } \\
\text { livestock water. }\end{array}$ & $\begin{array}{l}\text { T. } 35 \text { S., R. } 30 \text { E., } \\
\text { Secs. } 1,12,13,24 \text {. } \\
25, \text { and } 36 \\
\text { T. } 34 \text { S., R. } 30 \text { E., } \\
\text { Sec. } 33\end{array}$ & None & $\begin{array}{l}\text { EA is completed. } \\
\text { Decision Record } \\
\text { signed. }\end{array}$ \\
\hline $\begin{array}{l}\text { Primary Contact: } \\
\text { Dave Ward }\end{array}$ & & $\begin{array}{l}\text { The purpose of this action is to } \\
\text { adjust and manage winter } \\
\text { grazing as a result of the Act. }\end{array}$ & & & \\
\hline
\end{tabular}




\begin{tabular}{|c|c|c|c|c|c|}
\hline $\begin{array}{l}\text { EA Register } \\
\text { Number }\end{array}$ & Project Name & Proposed Action & Location & $\begin{array}{l}\text { Critical } \\
\text { Element }\end{array}$ & $\begin{array}{c}\text { Completion } \\
\text { Date/Decision/ } \\
\text { Action }\end{array}$ \\
\hline $\begin{array}{l}\text { EA } \\
\text { OR-026-01-09 }\end{array}$ & $\begin{array}{l}\text { Coyote Lake/ } \\
\text { Alvord-Tule } \\
\text { Springs Wild } \\
\text { Horse Removal }\end{array}$ & $\begin{array}{l}\text { The proposed action is to } \\
\text { remove horses to maintain } \\
\text { proper herd number. }\end{array}$ & $\begin{array}{l}\text { Alvord-Tule Springs } \\
\text { and Coyote Lake } \\
\text { HMAs }\end{array}$ & WSA & $\begin{array}{l}\text { Decision Record } \\
\text { was signed } \\
\text { December 7, } 2000 .\end{array}$ \\
\hline $\begin{array}{l}\text { Primary Contact: } \\
\text { Carolyn Chad }\end{array}$ & & $\begin{array}{l}\text { The purpose of this action is to } \\
\text { maintain AMLs of this herd. }\end{array}$ & & & $\begin{array}{l}\text { Sixty-nine horses } \\
\text { were removed } \\
\text { January } 2001 \text {. }\end{array}$ \\
\hline $\begin{array}{l}\text { EA } \\
\text { OR-026-01-15 }\end{array}$ & $\begin{array}{l}\text { High Desert Trail } \\
\text { Maintenance }\end{array}$ & $\begin{array}{l}\text { The proposed action is minor } \\
\text { trail maintenance. }\end{array}$ & $\begin{array}{l}\text { Wildhorse, Little } \\
\text { Blitzen, and Big }\end{array}$ & WSA & EA is complete. \\
\hline $\begin{array}{l}\text { Primary Contact: } \\
\text { Mary Emerick }\end{array}$ & & $\begin{array}{l}\text { The purpose of this action is } \\
\text { for trail maintenance to } \\
\text { facilitate hiking opportunities } \\
\text { and prevent resource damage. }\end{array}$ & Indian Canyons & & $\begin{array}{l}\text { Decision Record } \\
\text { signed. }\end{array}$ \\
\hline $\begin{array}{l}\text { EA } \\
\text { OR-026-01-20 }\end{array}$ & Gap Reservoir & $\begin{array}{l}\text { The proposed action is to } \\
\text { construct one-half acre foot } \\
\text { reservoir and on e-quarter mile } \\
\text { fence. }\end{array}$ & $\begin{array}{l}\text { T. } 32 \text { S., R } 321 / 2 \text { E., } \\
\text { Sec. } 3\end{array}$ & WSA & EA is in process. \\
\hline $\begin{array}{l}\text { Primary Contact: } \\
\text { Dave Ward }\end{array}$ & & $\begin{array}{l}\text { The purpose of this action is to } \\
\text { improve livestock distribution } \\
\text { in Mud Creek Allotment and } \\
\text { eliminate livestock use from } \\
\text { perennial streams (Bridge } \\
\text { Creek and Mud Creek). }\end{array}$ & & & \\
\hline $\begin{array}{l}\text { Primary Contact: } \\
\text { Carolyn Chad }\end{array}$ & $\begin{array}{l}\text { Starr Winter } \\
\text { Pasture }\end{array}$ & $\begin{array}{l}\text { The proposed action is to } \\
\text { change seas on of use. } \\
\text { The purpose of this action is to } \\
\text { change time of use from } \\
\text { November } 1 \text { - February } 28 \text { to } \\
\text { February } 1 \text { - March } 31 \text { to } \\
\text { better meet allotment } \\
\text { objectives of increasing } \\
\text { perennial vegetation. }\end{array}$ & $\begin{array}{l}\text { Pueblo Mountain } \\
\text { Allotment Winter } \\
\text { Pasture }\end{array}$ & None & $\begin{array}{l}\text { EA written and } \\
\text { Decision Record } \\
\text { signed April 10, } \\
2001 .\end{array}$ \\
\hline $\begin{array}{l}\text { EA } \\
\text { OR-026-01-24 }\end{array}$ & $\begin{array}{l}\text { Lower Grassy } \\
\text { Pipeline } \\
\text { Extension }\end{array}$ & $\begin{array}{l}\text { The proposed action is to bury } \\
1 \frac{1 / 4}{} \text { mile of pipeline and install } \\
\text { trough. }\end{array}$ & $\begin{array}{l}\text { Grassy Basin } \\
\text { Allotment }\end{array}$ & None & EA is in process. \\
\hline $\begin{array}{l}\text { Primary Contact: } \\
\text { Rick Hall }\end{array}$ & & $\begin{array}{l}\text { The purpose of this action is to } \\
\text { improve livestock distribution } \\
\text { and implement projects } \\
\text { identified in the AMP. }\end{array}$ & & & \\
\hline $\begin{array}{l}\text { Primary Contact: } \\
\text { Evelyn Treiman }\end{array}$ & $\begin{array}{l}\text { Willamette Valley } \\
\text { Soaring Club }\end{array}$ & $\begin{array}{l}\text { The proposed action is the } \\
\text { annual gathering of gliders. } \\
\text { The purpose of this action is to } \\
\text { allow a specialized activity that } \\
\text { is limited due to lack of public } \\
\text { land areas suitable for } \\
\text { launching and landing gliders. }\end{array}$ & Alvord Playa & WSA & $\begin{array}{l}\text { EA is complete. } \\
\text { Decision Record } \\
\text { signed. }\end{array}$ \\
\hline
\end{tabular}




\begin{tabular}{|c|c|c|c|c|c|}
\hline $\begin{array}{c}\text { EA Register } \\
\text { Number }\end{array}$ & Project Name & Proposed Action & Location & $\begin{array}{l}\text { Critical } \\
\text { Element }\end{array}$ & $\begin{array}{c}\text { Completion } \\
\text { Date/Decision/ } \\
\text { Action }\end{array}$ \\
\hline $\begin{array}{l}\text { EA } \\
\text { OR-027-01-10 }\end{array}$ & $\begin{array}{l}\text { Page Springs } \\
\text { Birding Trail }\end{array}$ & $\begin{array}{l}\text { The proposed action is to } \\
\text { construct } 4.9 \text { miles of trail } \\
\text { (joint Malheur National } \\
\text { Wildlife Refuge/BL M). }\end{array}$ & $\begin{array}{l}\text { Page Springs } \\
\text { Campground Area }\end{array}$ & None & $\begin{array}{l}\text { EA dropped with } \\
\text { the proposal } \\
\text { included in } \\
\text { Steens/Andrews } \\
\text { RMP. }\end{array}$ \\
\hline $\begin{array}{l}\text { Primary Contact: } \\
\text { Mary Emerick }\end{array}$ & & $\begin{array}{l}\text { The purpose of this action is to } \\
\text { provide hiking and } \\
\text { birdwatching opportunities in } \\
\text { the vicinity of Page Springs } \\
\text { Campground. }\end{array}$ & & & \\
\hline $\begin{array}{l}\text { EA } \\
\text { OR-027-01-27 }\end{array}$ & $\begin{array}{l}\text { Steens } \\
\text { Implementation } \\
\text { Projects }\end{array}$ & $\begin{array}{l}\text { The proposed action is to build } \\
\text { new fences, to remove old } \\
\text { unneeded fences, and to } \\
\text { develop water sources to } \\
\text { comply with the SMAC } \\
\text { legislation. }\end{array}$ & $\begin{array}{l}\text { Steens Mountain } \\
\text { Area }\end{array}$ & $\begin{array}{l}\text { Wilderness, } \\
\text { WSA, ACEC }\end{array}$ & $\begin{array}{l}\text { EA written. } \\
\text { Decision Record } \\
\text { signed July } 27 \text {, } \\
2001 .\end{array}$ \\
\hline $\begin{array}{l}\text { Primary Contact: } \\
\text { Matt Obradovich }\end{array}$ & & $\begin{array}{l}\text { The purpose of this action is to } \\
\text { implement key features of the } \\
\text { Act, including forage } \\
\text { replacement for the "No } \\
\text { Livestock Grazing Area" } \\
\text { portion of the Wilderness } \\
\text { Area. }\end{array}$ & & & \\
\hline $\begin{array}{l}\text { EA } \\
\text { OR-027-01-35 }\end{array}$ & Cycle Oregon & $\begin{array}{l}\text { The proposed action is to } \\
\text { analyze impacts of a large } \\
\text { group of people to take bus } \\
\text { tours of the Steens Mountain. }\end{array}$ & $\begin{array}{l}\text { Steens Mountain } \\
\text { Loop Road }\end{array}$ & WSA & $\begin{array}{l}\text { EA was completed } \\
\text { with Decision } \\
\text { Record signed } \\
\text { August } 2001 .\end{array}$ \\
\hline $\begin{array}{l}\text { Primary Contact: } \\
\text { Mark Sherbourne }\end{array}$ & & $\begin{array}{l}\text { The purpose of this action is to } \\
\text { allow large number of people } \\
\text { to tour the Steens, in a short } \\
\text { period of time. }\end{array}$ & & & Tour was allowed. \\
\hline $\begin{array}{l}\text { EA } \\
\text { OR-027-02-011 }\end{array}$ & $\begin{array}{l}\text { Steens Mountain } \\
\text { Wilderness } \\
\text { Inholding Access }\end{array}$ & $\begin{array}{l}\text { The proposed action is to } \\
\text { auth orize reasonable mo torized } \\
\text { access for land owners to } \\
\text { private land completely } \\
\text { surrounded by wilderness. }\end{array}$ & $\begin{array}{l}\text { Designated } \\
\text { Wilderness }\end{array}$ & Wildeness & EA is in process. \\
\hline $\begin{array}{l}\text { Primary Contact: } \\
\text { Mary Emerick }\end{array}$ & & $\begin{array}{l}\text { The purpose of this action is to } \\
\text { comply with the directives of } \\
\text { the Act. }\end{array}$ & & & \\
\hline $\begin{array}{l}\text { EA } \\
\text { OR-027-02-12 }\end{array}$ & $\begin{array}{l}\text { Steens Mountain } \\
\text { Wilderness } \\
\text { Grazing Access }\end{array}$ & $\begin{array}{l}\text { The proposed action is to allow } \\
\text { occasional motorized vehicle } \\
\text { access for grazing permittees. }\end{array}$ & $\begin{array}{l}\text { Designated } \\
\text { Wilderness }\end{array}$ & Wilderness & EA is in process. \\
\hline $\begin{array}{l}\text { Primary Contact: } \\
\text { Mary Emerick }\end{array}$ & & $\begin{array}{l}\text { The purpose of this action is to } \\
\text { comply with the directives of } \\
\text { the Act. }\end{array}$ & & & \\
\hline
\end{tabular}


BLM Library

Cienver Federal Center

Bldg. 50, OC-521

P.O. Box 25047

Denver, CO 80225 
UNITED STATES

DEPARTMENT OF THE INTERIOR

BUREAU OF LAND MANAGEMENT

Burns District Office

28910 Hwy 20 West

Hines, Oregon 97738

OFFICIAL BUSINESS

PENALTY FOR PRIVATE USE, $\$ 300$

USDI BLM DENVER SERVICE CENTER LIBRARY

BUILDING 50

DENVER CO 80225

$\left|I_{1} l_{1}\left\|_{1, \ldots},\left.\left.l_{1}\right|_{1} l_{1} l_{1}\right|_{1} l_{1,1}\right\|_{1}\right|$

FIRST CLASS

POSTAGE \& FEES PAID

Bureau of Land Management

Permit No. G-76 